\title{
5 \\ Connecting locals to locals: Market discovery through e-commerce
}

Voraprapa Nakavachara and Santitarn Sathirathai

\section{Introduction}

The digital economy, once a fringe market, has experienced remarkable growth globally. Technological advancements and the increasing ubiquity of affordable internet and internet-enabled devices have led to a spate of industries being disrupted and digitised. Though its introduction in Southeast Asia occurred far later than in the West, the digital economy throughout the region has seen a massive leap in growth. A report by Google and Temasek (2018) estimates that the internet economy within ASEAN+6 (defined as Indonesia, Malaysia, the Philippines, Singapore, Thailand and Vietnam) more than doubled, from US $\$ 32$ billion in 2015 to US\$72 billion in 2018. One of the digital economy's most successful constituents, accounting for roughly 31 per cent of ASEAN+6's digital economy in 2018, is e-commerce, which refers to the activity of transacting goods and services over the internet.

Despite the unprecedented proliferation of e-commerce, there has been little detailed academic research on it within the region. While there is some literature on e-commerce's effects on buyers, there has been little attention given to the sellers on these platforms in ASEAN. This chapter therefore aims to contribute to the literature by examining the 
e-commerce industry in Thailand through the perspective of its impact on online sellers. More specifically, the objective of the chapter is to assess the effects of e-commerce on the broader economy through changes in firm-level efficiency and market connectivity. In particular, we explore the impact of e-commerce adoption on the sellers' geographical reach, business revenue, profit growth and, ultimately, household income.

We chose to focus on Thailand for a number of reasons. First, Thailand has a burgeoning e-commerce industry that is rapidly growing. This is partly due to a large number of aspiring entrepreneurs and social sellers. ${ }^{1}$ Second, Thailand has an ideal composition of traditional, brick-andmortar small and medium-sized enterprises (SMEs) and 'pure' online sellers (defined as sellers with no offline stores). Third, the government is pushing for the development of the digital economy, especially for SMEs, under the 'Thailand 4.0' plan.

One problem that is common to much of the previous literature on e-commerce sellers is sourcing data. A combination of limited access to sellers and low response rates results in relatively small sample sizes. These sample sizes were often not large enough for researchers to extensively analyse and address their research questions. To overcome this problem, we have worked closely with Sea Group and its e-commerce platform, Shopee, to construct a dataset from a novel and large-scale survey of sellers on Shopee. The benefit of collaborating with Shopee is that not only is it one of the largest e-commerce platforms in Southeast Asia, but also it has one of the most diverse seller communities. Sellers on Shopee range from pure online microentrepreneurs to traditional SMEs and larger companies, and cover various product categories. With the help of the Shopee team, we were able to get close to 7,000 merchant responses—enough to construct a sizeable microdataset for in-depth and unique analyses. The richness of the data also allows for connectivity analysis using mapping visualisations as well as regression analyses on various subsamples.

1 Social sellers are online sellers who participate in social commerce. Social commerce can refer to transactions on social media platforms (for example, Facebook, Instagram), sellers promoting products and sales through social media but transacting on an e-commerce platform or using social networking services (for example, live chat, live stream) native to the e-commerce platform before completing the transaction on the said platform. For disambiguation, we will henceforth refer to the first case as social commerce and the latter two as socially enabled e-commerce. 
Utilising the constructed dataset, this chapter finds that e-commerce adoption is associated with improvement in sellers' household incomes. The benefits come from two channels. First, e-commerce empowers existing SMEs by significantly boosting their revenue, efficiency and profit growth. The improvement in profitability goes beyond a one-off gain as moving online seems to also result in stronger profit growth rates. Second, our trade connectivity analysis illustrates how e-commerce allows merchants, especially those in poorer regions, to discover new market opportunities outside their own region.

Due to data limitations, we were only able to analyse the sellers who eventually engaged in e-commerce. We were not able to examine the traditional sellers that had not yet gone online and compare the results. We note this as a limitation of our current study and encourage future research to revisit this issue once the required data are available.

The chapter is structured as follows. Section two provides an overview of the e-commerce landscape within the region and in Thailand. Section three provides a brief literature review, while section four outlines the survey methodology and data. Section five begins the main empirical investigation and explores the economic impact of e-commerce using regression analysis, by looking at the impact on sellers' revenue, profit growth and efficiency (proxied by revenue per employment). Section six delves into the impact of e-commerce on seller connectivity, by way of market discovery, through the use of connectivity diagrams. Section seven discusses this chapter's overall findings and is followed by conclusions, policy implications and recommendations.

\section{E-commerce landscape}

E-commerce is defined as 'the activity of transacting goods and services over the internet'. The most common forms of e-commerce are businessto-consumer (B2C), consumer-to-consumer (C2C), consumer-to-business (C2B) and business-to-business (B2B) (UNESCAP and ADB 2018).

This chapter will focus on $\mathrm{B} 2 \mathrm{C}$ and $\mathrm{C} 2 \mathrm{C}$ due to data availability. $\mathrm{B} 2 \mathrm{C}$ is where businesses sell to consumers and more naturally lends itself to electronic retailing (e-tailing) and marketplace e-commerce. On the other hand, $\mathrm{C} 2 \mathrm{C}$ is where users (consumers) of an e-commerce platform can be the buyer, seller or both, and is most commonly done through marketplace e-commerce or social commerce. 


\section{E-commerce in Southeast Asia}

E-commerce has seen unprecedented growth within the region, with total gross merchandise value (GMV) of $\mathrm{B} 2 \mathrm{C}$ and $\mathrm{C} 2 \mathrm{C}$ estimated to have more than doubled in a single year, from US $\$ 11$ billion in 2017 to US $\$ 23$ billion in 2018 , and it is projected to grow to US $\$ 102$ billion by 2025 (Google and Temasek 2018). However, despite its current scale, e-commerce in Southeast Asia still lags far behind more mature e-commerce markets. According to Sathirathai and Wan (2018), in 2017, e-commerce penetration within the region averaged approximately 2 per cent of the population, which is far below both China and the United States, at roughly 23 per cent and 8 per cent, respectively. In context, e-commerce penetration of 2 per cent would put ASEAN+6 where China was in 2010-roughly seven years behind. This number only serves to highlight the nascence of the industry and, despite an already impressive compound annual growth rate of 39 per cent from 2015 to 2018, the industry is expected to grow even further.

It is important to note, however, that ASEAN+6 has characteristics unique to the region that have led to the evolution of business models different from those in other regions. The recent development of low-cost entrylevel smartphones has led to a population that accesses the internet with a mobile phone first and, in most cases, a mobile only. Data from Google's Consumer Barometer (Think with Google 2017) reveal that smartphone ownership is at 74 per cent in the region, while only 40 per cent of people use a computer. In addition, 63 per cent of respondents claim they access the internet more often via smartphone than via computer or tablet. This trend is also reflected in mobile e-commerce penetration, for which around 68 per cent of internet users in ASEAN +6 have made a purchase online via mobile in the past month, while China and the United States have penetration rates of 74 per cent and 44 per cent, respectively (Kemp 2019b).

Lack of offline retail in ASEAN+6 and low urbanisation rates have supported the growth of $\mathrm{C} 2 \mathrm{C}$ marketplaces. This form of e-commerce is made up almost entirely of independent sellers, the majority of which are SMEs. In Indonesia, McKinsey \& Company (2018) estimates that, of the 4.5 million active sellers in 2017, 99 per cent were microenterprises. Furthermore, they estimate that 15 per cent of all sellers are selling their own products. The region is also highly social media-centric, resulting in the popularity of both social commerce and socially enabled e-commerce. 
For example, McKinsey \& Company (2018) estimates that more than 37 per cent of Indonesia's e-commerce value is generated through social commerce, with roughly one-third of all online shoppers being purely social commerce users.

\section{E-commerce in Thailand}

Thailand had an estimated e-commerce GMV of US $\$ 3$ billion in 2018, which was roughly 13 per cent of the region's total. Many of the drivers of the prosperity of e-commerce in the region can be found in Thailand. On top of already favourable demographics, a report by Sea and the World Economic Forum (WEF) (2018) finds that Thailand has the greatest propensity for entrepreneurship within Southeast Asia, with 36 per cent of youths aspiring to be entrepreneurs in the future, compared with a regional average of 25 per cent. Additionally, Thailand boasts a social media-centric population that is largely mobile-first. It is estimated that approximately 51 per cent of consumers buy goods through social media and the value of social commerce is roughly half of the total e-commerce market.

In terms of connectivity drivers, Thailand completed its Village Broadband Internet Project (Net Pracharat) in 2017. The government installed and provided free broadband internet to 24,700 rural villages throughout the country. In 2018, Thailand's internet penetration rate was 82 per cent (Kemp 2019a), which grew significantly from 27 per cent in 2011 (Kemp 2011). The country's average fixed internet connection speed is 57.6 megabits per second (Mbps) - higher than the world average of 54.3 Mbps. Thailand's mobile broadband connectivity (broadband mobile connections per capita) is 133 per cent, which is higher than the global average of 74 per cent.

Thailand also has unique online consumer behaviour. Banking penetration is relatively high in Thailand at 81 per cent of the population aged above 15 years, compared with a regional average of 55 per cent (World Bank 2017). While bank transfers are the most popular form of online payment, constituting 28 per cent of all online payments, cash on delivery remains highly preferred, at 20 per cent (Worldpay 2018). A survey conducted by ecommerceIQ (2018) finds the top two things Thai online shoppers value most are cheap product prices and great product selection. This may reflect the fact that more than half of online shoppers are outside Bangkok and may be more sensitive to price and product diversity. 
Despite its already impressive growth, the outlook for Thailand's e-commerce industry is still very positive. While Thailand's e-commerce market is estimated to account for less than 1 per cent of retail sales, it is expected to rise to 5 per cent over the next five years (Jones and Pimdee 2017). This is expected to be further supported by the government's recent launch of the Thailand 4.0 initiative, announced in October 2018 (Royal Thai Embassy n.d.). The third of the five agendas outlined in the announcement of the initiative focuses on incubating entrepreneurs and developing 'networks of innovation-driven enterprise'. One objective of the agenda is to increase the current contribution of SMEs from 37 per cent of total GDP to 50 per cent within 10 years through access to financing, skills development and supporting the enhancement of digital transformation. The government has also announced plans to develop 100 smart cities within two decades as part of another agenda within the Thailand 4.0 initiative, thus further connecting more individuals and creating a more supportive environment for digital ventures (Christopher 2018).

\section{Literature review}

The digital revolution has changed society in many ways. From a communication standpoint, online connectivity has led to the 'death of distance' in that the physical distance between people is becoming less relevant and no longer constrains our ability to communicate and interact with one another.

Focusing on international trade, the literature has documented that the value and amount of trade are inversely related to the distance between the locations of the parties involved in the trade transaction (Lendle et al. 2016). This is because the further the distance between the parties, the higher are the costs of communication and trade arrangements. With e-commerce taking off in the past decade, the costs of trade have dramatically reduced. In addition, e-commerce benefited the economy as a whole in terms of lowering trade barriers, increasing employment and enhancing economic development (McKinsey \& Company 2018).

The literature also documents the benefits of e-commerce from both the sellers' and the buyers' perspectives. From the sellers' point of view, e-commerce eliminates the cost of setting up actual physical stores, provides alternative means of earning and makes it easier to become an entrepreneur (Fan et al. 2018; Dai and Zhang 2016). From the buyers' 
point of view, e-commerce reduces search costs, allows access to a broader variety of products and makes it easier to buy things from far away (Dolfen et al. 2019).

Most of the recent literature on e-commerce has focused on China, as the country's e-commerce sector recently experienced accelerated growth. Fan et al. (2018), using data from Alibaba Inc., document that e-commerce increases domestic trade within China. In addition, the adoption of e-commerce increases welfare from the sellers' perspective. Couture et al. (2018) evaluated the Chinese Government's nationwide e-commerce expansion program and conclude that it reduced logistical barriers and resulted in sizeable welfare gains. However, the young and the rich appeared to benefit more from the program than any other group of people. Dai and Zhang (2016), using firm registry data, show that e-commerce helps people with limited financial and social capital to become entrepreneurs. Huang et al. (2018) find that people residing in areas with higher levels of e-commerce adoption are more likely to be entrepreneurs.

Despite explosive growth in e-commerce in Southeast Asia in recent years, only a limited number of studies have investigated the impact of e-commerce in the region. Wong (2003) argues that Singapore's infrastructure and its people's readiness should allow the country to be a very fast adopter of e-commerce. Rowe et al. (2012) studied the factors driving e-commerce adoption in Vietnam and found that, among others, the knowledge and resources available to enterprises and the positive attitude of management towards technology were the most important factors. McKinsey \& Company (2018) explore the Indonesian e-commerce market and conclude that e-commerce helps increase sales and employment. For Thailand, Cheewatrakoolpong and Mallikamas (2019) study factors determining whether e-commerce sellers would export their products. Among others, the factors determining whether they would export are the number of years in operation and the types of products they sell.

To the best of our knowledge, this chapter is the first to utilise a relatively large survey (close to 7,000 observations) of e-commerce sellers in Thailand to analyse the impact of e-commerce on sellers' household income, revenue, profitability, efficiency and connectivity. Many of the previous studies that tried to investigate impacts from the sellers' side were unable to collect a decent-sized survey due to low response rates. We overcome this problem by working closely with Sea Group and Shopee, its e-commerce platform, to launch and collect the survey data. 


\section{The survey and data}

The data used in this chapter are from a survey we conducted with the assistance of Sea Group and its Shopee team. The survey was prepared and conducted during 2018-19. The questions were sent (via the Shopee platform) to Shopee sellers who sold a minimum number of items over a six-month period. The sellers were provided with small incentives to participate in the survey. ${ }^{2}$

We would like to point out that, although we were able to launch an extensive survey, we were not able to build an actual panel dataset. Since this was a voluntary survey, we needed to find a balance between the information we wanted to get and the information the respondents would be willing to comfortably provide. Therefore, there was a limitation on the data we could obtain. To measure the changes associated with engaging in e-commerce, we asked sellers about their current situation (now they were online) and their previous situation (when they were not online or when they were just starting out). This information would allow us to visualise the impact-although not as accurately as if we were able to construct a panel dataset. Also, respondents could find some questions, such as those relating to profit, sensitive. Therefore, instead of asking about actual profits, we asked how their profits had changed after they engaged in e-commerce.

\section{Survey questions}

The survey questionnaire included three sets of broad questions as follows (see Appendix 5.1 for the full questionnaire).

\section{Questions on basic demographics}

We asked sellers for their basic demographic information such as age, gender, education, employment status, whether they were a primary earner for their household, their province of residence, and so on.

2 Although we launched the survey in a systematic way, we were not able to control who decided to answer the survey. Therefore, we cannot claim that the results represent the population of Shopee sellers or all Thai SMEs. However, in the section titled 'Thailand's SMEs versus our data', we compare the basic statistics in our data with those for all Thai SMEs to illustrate how they fit. 


\section{Questions on economic impacts of e-commerce}

To measure the economic impact of e-commerce, we have to segregate the sellers into two groups: existing SMEs and new entrepreneurs.

Existing SMEs are sellers with a prior offline business before going online. For these sellers, we asked questions about their prior offline business such as revenue, profit growth, the number of people employed including the owner, the location of the customers to whom they used to sell and so on. We asked when they started their online business. We then asked about their business since they moved online-information that included current revenue, profit growth, employment, the location of customers and so on. In addition, we asked them about the size of their online business relative to their entire business. In this chapter, we will call these questions 'Set A questions' and we will call these SMEs 'Group A sellers'.

New entrepreneurs are sellers with no prior offline business who are just starting their business purely online (a few may have subsequently set up an offline business). For these sellers, we asked questions about their current online business, including the year they started, current revenue, profit growth, employment, the location of their customers and so on. In this chapter, we will call these questions 'Set B questions' and these entrepreneurs 'Group B sellers'.

For both groups, we also asked whether entering into e-commerce (that is, selling online) had changed their household income. The response choices were: 'Decreased significantly', 'Decreased somewhat', 'Not much impact', 'Increased somewhat' and 'Increased significantly'.

\section{Other miscellaneous questions}

We are also interested in why the sellers decided to enter into e-commerce, so we asked them about the factors that motivated them to do so. Among the responses are 'External pressure (others are doing it)', 'Flexibility and better work-life balance' and 'Financial security'. We also asked questions about how they intended to spend the profits earned. 


\section{Thailand's SMEs versus our data}

To discuss how our data fit with those for all of Thailand's SMEs, we first discuss the overall summary statistics of Thailand's SMEs as provided by the Office of Small and Medium Enterprise Promotion (OSMEP). The aggregate data for Thailand's small enterprises (SEs), medium enterprises and SMEs in 2018 are shown in Table 5.1 (left panel). ${ }^{3}$ We separate the statistics for all enterprises and for enterprises in the wholesale and retail sector. ${ }^{4}$ According to the enterprise promotion office, there are $3,077,822$ SMEs in the Thai economy $(1,279,557$ of which are in the wholesale and retail sector). Only 23.03 per cent of the SMEs are registered as juristic entities. Thailand's SMEs accounted for THB7,013,971 in GDP and employed 13,950,241 people. The imputed average monthly sales are THB189,906 and the imputed average employment is 4.53 people.

Most of the SMEs (99.5 per cent) are actually small enterprises. Their imputed average monthly sales are THB136,302 and their imputed average employment is 4.14 people. Of the $3,063,651$ small enterprises, $1,275,470$ are in the wholesale and retail sector. Their imputed average monthly sales are THB122,749 and their imputed average employment is 3.33 people.

According to a ministerial regulation issued by Thailand's Ministry of Industry in 2002, SMEs in the retail sector are defined as enterprises with up to 30 employees or with assets (excluding land) of up to THB60 million. In our survey data, we have the information on employment but not on assets. Therefore, we applied this employment threshold to eliminate sellers who are not SMEs. We were able to gather 6,860 observations from the survey. Among them, 2,049 observations (29.9 per cent) belong to Group A and 4,811 observations (70.1 per cent) belong to Group B. ${ }^{5}$

3 Note that we were only able to gather the annual GDP and total employment. Therefore, we had to impute the estimated monthly sales (GDP/12/Number of enterprises) and the average employment (Total employment/Number of enterprises).

4 We were not able to segregate the retail sector from the wholesale sector.

5 We were able to collect the initial sample of 7,226 observations; however, we dropped those observations missing important information like gender and age. We also dropped observations that were extreme outliers (possibly due to input errors) — for example, negative age, negative revenue, negative employment and extremely high revenue growth (more than 10,000 per cent). Finally, we kept only the observations that were between the ages of 10 and 70 . We also excluded observations that were not SMEs by definition. After the cleaning process, we had 6,860 observations. 
5. CONNECTING LOCALS TO LOCALS

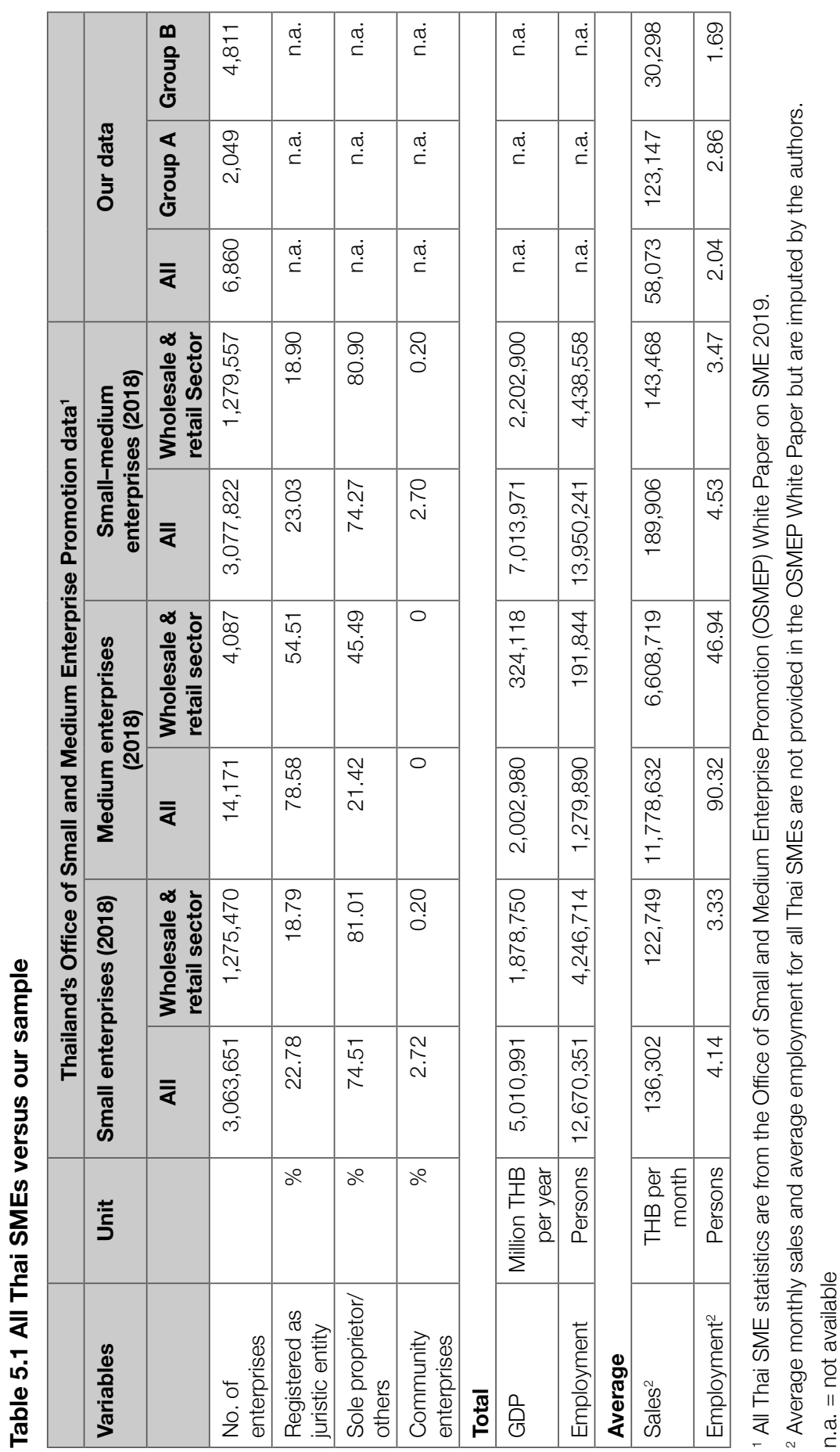


The basic summary statistics of our data are shown in Table 5.1 (right panel). Overall, average monthly sales are THB58,073 and average employment is 2.04 people. These statistics are lower than those for the total of Thai SMEs. However, looking at Group A and Group B separately, we find that Group A's statistics are comparable with those of Thailand's small enterprises in the wholesale and retail sector. Group A's average sales are THB123,147 and average employment is 2.86 people, whereas imputed average sales of Thailand's small enterprises in the wholesale and retail sector are THB122,749 and imputed average employment is 3.33. On the other hand, Group B's average sales of THB30,298 and average employment of 1.69 are far below those of Thailand's total SMEs. They are also lower than the average of Thailand's small enterprises.

\section{Summary statistics of the sellers}

Table 5.2 provides the detailed summary statistics of the sellers in our data. For the overall sample, the average age is 32.46 years. About 27.9 per cent of the survey respondents are male and about 45.3 per cent are the primary earner for their household. The majority (68.3 per cent) have a bachelor's degree as their highest education level. Also, the majority (43.4 per cent) are employed by organisations.

Table 5.2 Summary statistics

\begin{tabular}{|l|l|r|r|r|}
\hline \multicolumn{2}{|l|}{ Variables } & \multicolumn{1}{c|}{ All } & \multicolumn{1}{c|}{ Group A } & \multicolumn{1}{c|}{ Group B } \\
\hline No. of observations & 6,860 & 2,049 & 4,811 \\
\hline Age & Average (years) & 32.46 & 34.16 & 31.74 \\
\hline Male & $(\%)$ & 27.9 & 35.7 & 24.5 \\
\hline Primary earner & $(\%)$ & 45.3 & 52.0 & 42.5 \\
\hline \multirow{5}{*}{ Education } & Below high school (\%) & 2.5 & 2.5 & 2.5 \\
\cline { 2 - 5 } & High school (\%) & 7.0 & 6.0 & 7.5 \\
\cline { 2 - 5 } & Vocational (\%) & 4.9 & 5.1 & 4.8 \\
\cline { 2 - 5 } & Bachelor (\%) & 68.3 & 68.1 & 68.3 \\
\cline { 2 - 5 } & Advanced degree (\%) & 17.3 & 18.3 & 16.8 \\
\hline \multirow{5}{*}{ Employment } & Employed full-time (\%) & 41.6 & 25.1 & 48.7 \\
\cline { 2 - 5 } & Employed part-time (\%) & 1.8 & 1.9 & 1.8 \\
\cline { 2 - 5 } & Not employed: Homemaker (\%) & 7.0 & 4.3 & 8.2 \\
\cline { 2 - 5 } & Not employed: Retired (\%) & 0.5 & 0.2 & 0.6 \\
\cline { 2 - 5 } & Not employed: Student (\%) & 7.9 & 3.4 & 9.8 \\
\cline { 2 - 5 } & Other (\%) & 3.9 & 3.8 & 3.9 \\
\cline { 2 - 5 } & Self-employed (\%) & 5.7 & 2.8 & 6.9 \\
\cline { 2 - 5 } & Unemployed (\%) & & \\
& & & 58.5 & 20.2 \\
\hline
\end{tabular}


As mentioned above, we segregated our respondents into existing SMEs (Group A) and new entrepreneurs (Group B); therefore, we also computed the summary statistics for each of the groups separately. The average age of Group A is 34.16 and the average age of Group B is 31.74 years; 35.7 per cent of Group A and 24.5 per cent of Group B are male. Approximately 52 per cent of Group A and 42.5 per cent of Group $\mathrm{B}$ are the primary earner in their household. We conducted T-tests (of the difference in means) and can conclude that Group A is older than Group B, Group A has more men than Group B and Group A has more primary earners than Group B. ${ }^{6}$ The majority of both groups (68.1 per cent of Group A and 68.3 per cent of Group B) have a bachelor's degree as their highest level of education; Group A appears to be mostly self-employed (58.5 per cent) whereas Group B appears to be mostly employed by an organisation (50.5 per cent).

\section{Economic impact analysis}

In this section, we explore the potential economic impact of going online for individual sellers. We start by examining the impact on household income of e-commerce adoption. One of the survey questions we asked was how entering into e-commerce business (that is, starting to sell online) had changed each seller's household income; Table 5.3 summarises the responses. ${ }^{7}$ Overall, entering into e-commerce appears to have had a positive impact on household income for most sellers-in particular, 72 per cent reported that their household income increased due to e-commerce, with 16.3 per cent of respondents reporting a 'significant' increase. Looking at Group A (existing SMEs) and Group B (new entrepreneurs) separately, the former saw a higher proportion of households reporting income gains due to e-commerce. Among Group A, 82.4 per cent of households indicated income gains, with 22.8 per cent seeing a significant increase, while for Group B the numbers were 67.5 per cent and 13.5 per cent, respectively.

\footnotetext{
6 Specifically, the T-statistics are 11.906, 9.107 and 7.244 for the difference in the means of age, male (dummy) and primary earner (dummy), respectively.

7 See Appendix 5.1, Question 18 (for Set A) and Question 16 (for Set B).
} 
Table 5.3 Change in household income after entering e-commerce

\begin{tabular}{|l|r|r|r|r|r|r|}
\hline \multirow{2}{*}{ Answer } & \multicolumn{2}{|c|}{ All } & \multicolumn{2}{c|}{ Group A } & \multicolumn{2}{c|}{ Group B } \\
\cline { 2 - 7 } & \multicolumn{1}{|c|}{ Freq. } & \multicolumn{1}{c|}{$\%$} & \multicolumn{1}{c|}{ Freq. } & \multicolumn{1}{c|}{$\%$} & \multicolumn{1}{c|}{ Freq. } & \multicolumn{1}{c|}{$\%$} \\
\hline Decreased significantly & 18 & 0.3 & 18 & 0.9 & 0 & 0.0 \\
\hline Decreased somewhat & 137 & 2.0 & 33 & 1.6 & 104 & 2.2 \\
\hline Not much impact & 1,755 & 25.8 & 308 & 15.1 & 1,447 & 30.3 \\
\hline Increased somewhat & 3,793 & 55.7 & 1,212 & 59.6 & 2,581 & 54.0 \\
\hline Increased significantly & 1,110 & 16.3 & 464 & 22.8 & 646 & 13.5 \\
\hline Total & $\mathbf{6 , 8 1 3}$ & $\mathbf{1 0 0 . 1}$ & $\mathbf{2 , 0 3 5}$ & $\mathbf{1 0 0 . 0}$ & $\mathbf{4 , 7 7 8}$ & $\mathbf{1 0 0 . 0}$ \\
\hline
\end{tabular}

Next, we explore the mechanisms through which e-commerce adoption could contribute to higher household income for merchants. For existing SMEs, the key mechanism is likely to be improvement in profitability coming from rising sales and higher efficiency-that is, generating more revenue without ballooning costs. For new entrepreneurs, online channels may help provide additional income. We employ different empirical investigation methods to examine each group below.

\section{Economic analysis for existing SMEs (Group A)}

Recalling that Group A sellers had an offline business before moving online, we were able to collect data related to their business performance before and after they went online. The dependent variable of interest for Group A sellers is the change in their performance measures. Specifically, we will first explore the economic impact on sellers via increased revenue and profit growth. Then we explore how entering into e-commerce helped improve their business efficiency (as proxied by revenue per employment).

The empirical model used for the analysis is Equation 5.1.

\section{Equation 5.1}

$\Delta y_{i}=\alpha+\beta \cdot x_{i}+\theta_{p}+\gamma_{c}+\varepsilon_{i}$

In Equation 5.1, $\Delta y_{i}$ represents changes in the dependent variables of seller $I$, which are: 1 ) percentage change in revenue before versus after the seller went online, 2) change in profit growth before versus after the seller went online and 3) change in efficiency (change in revenue per employee before versus after the seller went online). Note that, for profits, we can only compare change in the growth rates - that is, acceleration-and not 
the level of profit due to the nature of the survey questions. This means the measure will not capture any potential level shift in profits after merchants go online.

In Equation 5.1, $x_{i}$ is a vector of observable characteristics of seller $i$. The key variable of interest is the degree of digital integration measured by the size of the online business relative to the entire business (constructed as group dummies with the base group being the sellers who have at most 20 per cent of their business online; other groups are 20-40 per cent, 40-60 per cent, $60-80$ per cent and $80-100$ per cent). ${ }^{8}$ We anticipate that the higher the degree of digital integration, the higher will be the positive impact of e-commerce on the SME in terms of revenue, profit and efficiency.

The other variables (which are the components of the vector $x_{i}$ ) include the number of people employed (including the seller) prior to going online and years in operation of the business. The first variable is a control for the size of the business prior to going online. The second variable is a control for how long the SME has been in operation. It is possible that older SMEs are more likely to be traditional and may not be able to adjust quickly to e-commerce. We also include the information on the age and gender of the seller, their highest education level (constructed as group dummies with the base group being sellers with lower than high school education; other groups are high school, vocational, bachelor and an advanced degree) and a dummy indicating whether they entered e-commerce because of external pressure. In Equation 5.1, $\theta_{p}$ is the province dummy; $\gamma_{c}$ is the main product category dummy; and $\varepsilon_{i}$ is the error term. We use the robust standard errors clustered by province. For each of the dependent variables, we run three regressions; the first regression (the base analysis) has neither the province nor the product category dummies, the second regression has the province dummies but no product category dummies and the last regression has both the province dummies and the product category dummies.

The results are shown in Table 5.4. Columns (1) to (3) display the results for the percentage increase in revenue. The SMEs with a moderate to high online presence ( 40 per cent or higher) are more likely to experience

8 Specifically, the base group are sellers with at most 20 per cent of their business online. The subsequent groups are sellers with more than 20 per cent but not more than 40 per cent online, sellers with more than 40 per cent but not more than 60 per cent online, sellers with more than 60 per cent but not more than 80 per cent online and sellers with more than 80 per cent up to 100 per cent online. 
a higher revenue increase after going online. Specifically, the SMEs that have 40-60 per cent of their business online experienced a 42.2 to 45.3 percentage point higher change in revenue compared with the base group (sellers with at most 20 per cent of their business online). SMEs that have $60-80$ per cent of their business online and those with $80-100$ per cent experienced a 99.72 to 103.5 percentage point and 280 to 284.6 percentage point higher percentage change, respectively, in revenue compared with the base group. This confirms our hypothesis that the higher the degree of digital integration, the higher is the positive impact of e-commerce on the SMEs in terms of revenue increase.

Table 5.4 Impact on sellers (Group A)

\begin{tabular}{|c|c|c|c|}
\hline & (1) & (2) & (3) \\
\hline Variable & $\begin{array}{l}\text { Percent_Inc } \\
\text { Rev }\end{array}$ & $\begin{array}{l}\text { Percent_Inc } \\
\text { Rev }\end{array}$ & $\begin{array}{l}\text { Percent_Inc } \\
\text { Rev }\end{array}$ \\
\hline \multirow[t]{2}{*}{ PercentOnline_A_20_40 } & 5.635 & 4.665 & 9.980 \\
\hline & (33.10) & (35.96) & (35.59) \\
\hline \multirow[t]{2}{*}{ PercentOnline_A_40_60 } & $42.18^{*}$ & 38.82 & $45.32^{\star \star}$ \\
\hline & (22.78) & (25.29) & (22.71) \\
\hline \multirow[t]{2}{*}{ PercentOnline_A_60_80 } & $99.72^{\star \star *}$ & $103.5^{\star \star \star}$ & $100.9^{\star \star \star}$ \\
\hline & (20.88) & (22.09) & (22.10) \\
\hline \multirow[t]{2}{*}{ PercentOnline_A_80_100 } & $280.0^{\star \star *}$ & $281.5^{\star \star \star}$ & $284.6^{\star \star \star}$ \\
\hline & (68.62) & (71.59) & (70.53) \\
\hline \multirow[t]{2}{*}{ PriorEmp_A } & -2.209 & -2.360 & -2.574 \\
\hline & $(1.719)$ & $(1.866)$ & (1.922) \\
\hline \multirow[t]{2}{*}{ YearsInOperation_A } & -0.684 & -0.840 & -0.976 \\
\hline & $(0.874)$ & $(0.962)$ & $(1.273)$ \\
\hline \multirow[t]{2}{*}{ Age } & -2.350 & -2.431 & -2.325 \\
\hline & (1.751) & (1.829) & (1.914) \\
\hline \multirow[t]{2}{*}{ Male } & -14.26 & -21.68 & -27.89 \\
\hline & (13.84) & (15.43) & (17.78) \\
\hline \multirow[t]{2}{*}{ RC_Education = 2, High School } & -10.46 & 4.888 & 12.84 \\
\hline & $(27.99)$ & (31.71) & (32.99) \\
\hline \multirow[t]{2}{*}{ RC_Education = 3, Vocational } & 4.575 & 16.05 & 27.27 \\
\hline & $(39.07)$ & $(41.11)$ & $(43.60)$ \\
\hline \multirow[t]{2}{*}{ RC_Education $=4$, Bachelor } & 18.70 & 32.84 & 32.74 \\
\hline & $(27.87)$ & (26.99) & $(30.37)$ \\
\hline
\end{tabular}




\begin{tabular}{|c|c|c|c|}
\hline & (1) & (2) & (3) \\
\hline Variable & $\begin{array}{c}\text { Percent_Inc } \\
\text { Rev }\end{array}$ & $\begin{array}{c}\text { Percent_Inc } \\
\text { Rev }\end{array}$ & $\begin{array}{c}\text { Percent_Inc_ } \\
\text { Rev }\end{array}$ \\
\hline \multirow{2}{*}{$\begin{array}{l}\text { RC_Education = 5, } \\
\text { Advanced degree }\end{array}$} & 13.91 & 24.64 & 23.83 \\
\hline & $(28.59)$ & $(27.05)$ & $(28.60)$ \\
\hline \multirow[t]{2}{*}{ ExtPressure_W } & -0.322 & 1.470 & 4.021 \\
\hline & $(17.23)$ & $(18.47)$ & (19.89) \\
\hline \multirow[t]{2}{*}{ Constant } & $171.8^{\star \star \star}$ & $470.8^{\star \star \star}$ & $689.9^{\star \star \star}$ \\
\hline & $(56.61)$ & $(65.25)$ & $(86.51)$ \\
\hline Observations & 1,964 & 1,964 & 1,919 \\
\hline R-squared & 0.030 & 0.048 & 0.057 \\
\hline Province dummies & No & Yes & Yes \\
\hline Product dummies & No & No & Yes \\
\hline \multirow[t]{2}{*}{ Sample } & Group A & Group A & Group A \\
\hline & (4) & (5) & (6) \\
\hline Variables & $\begin{array}{c}\text { Inc } \\
\text { ProfitGrowth }\end{array}$ & $\begin{array}{c}\text { Inc } \\
\text { ProfitGrowth }\end{array}$ & $\begin{array}{c}\text { Inc } \\
\text { ProfitGrowth }\end{array}$ \\
\hline \multirow[t]{2}{*}{ PercentOnline_A_20_40 } & $2.613^{\star \star \star}$ & $2.688^{\star \star \star}$ & $2.650^{\star \star \star}$ \\
\hline & $(0.475)$ & $(0.473)$ & $(0.457)$ \\
\hline \multirow[t]{2}{*}{ PercentOnline_A_40_60 } & $3.705^{\star \star \star}$ & $3.760^{\star \star \star}$ & $3.779^{\star \star \star}$ \\
\hline & $(0.346)$ & $(0.346)$ & $(0.371)$ \\
\hline \multirow[t]{2}{*}{ PercentOnline_A_60_80 } & $6.662^{\star \star \star}$ & $6.692^{\star \star \star}$ & $6.695^{\star \star \star}$ \\
\hline & $(0.524)$ & $(0.526)$ & $(0.526)$ \\
\hline \multirow[t]{2}{*}{ PercentOnline_A_80_100 } & $4.574^{\star \star \star}$ & $4.652^{\star \star \star}$ & $4.558^{\star \star \star}$ \\
\hline & $(0.763)$ & $(0.789)$ & $(0.801)$ \\
\hline \multirow[t]{2}{*}{ PriorEmp_A } & $-0.0938^{\star \star}$ & $-0.0916^{\star}$ & $-0.0878^{*}$ \\
\hline & $(0.0463)$ & $(0.0463)$ & $(0.0495)$ \\
\hline \multirow[t]{2}{*}{ YearsInOperation_A } & $-0.0281^{*}$ & $-0.0315^{\star}$ & -0.0331 \\
\hline & $(0.0167)$ & $(0.0175)$ & $(0.0271)$ \\
\hline \multirow[t]{2}{*}{ Age } & $-0.0318^{\star \star}$ & $-0.0339^{\star \star \star}$ & $-0.0294^{\star \star}$ \\
\hline & $(0.0128)$ & $(0.0123)$ & $(0.0129)$ \\
\hline \multirow[t]{2}{*}{ Male } & 0.514 & 0.667 & 0.688 \\
\hline & $(0.566)$ & $(0.561)$ & $(0.490)$ \\
\hline \multirow[t]{2}{*}{ RC_Education = 2, High school } & 1.409 & 1.622 & 1.390 \\
\hline & $(1.413)$ & $(1.520)$ & (1.554) \\
\hline
\end{tabular}


NEW DIMENSIONS OF CONNECTIVITY IN THE ASIA-PACIFIC

\begin{tabular}{|c|c|c|c|}
\hline & (4) & (5) & (6) \\
\hline Variables & $\begin{array}{c}\text { Inc } \\
\text { ProfitGrowth }\end{array}$ & $\begin{array}{c}\text { Inc } \\
\text { ProfitGrowth }\end{array}$ & $\begin{array}{c}\text { Inc } \\
\text { ProfitGrowth }\end{array}$ \\
\hline \multirow[t]{2}{*}{ RC_Education = 3, Vocational } & 1.370 & 1.754 & 1.770 \\
\hline & $(1.434)$ & $(1.494)$ & $(1.606)$ \\
\hline \multirow[t]{2}{*}{ RC_Education = 4, Bachelor } & 0.875 & 0.976 & 0.827 \\
\hline & $(1.257)$ & $(1.380)$ & $(1.457)$ \\
\hline \multirow{2}{*}{$\begin{array}{l}\text { RC_Education }=5 \text {, } \\
\text { Advanced degree }\end{array}$} & 0.783 & 0.948 & 0.826 \\
\hline & $(1.212)$ & $(1.335)$ & $(1.409)$ \\
\hline \multirow[t]{2}{*}{ ExtPressure_W } & 0.694 & $0.812^{*}$ & $0.914^{*}$ \\
\hline & $(0.470)$ & $(0.477)$ & $(0.461)$ \\
\hline \multirow[t]{2}{*}{ Constant } & 1.106 & -0.401 & 0.759 \\
\hline & $(1.402)$ & $(1.737)$ & $(2.950)$ \\
\hline Observations & 2,047 & 2,047 & 1,996 \\
\hline R-squared & 0.107 & 0.134 & 0.147 \\
\hline Province dummies & No & Yes & Yes \\
\hline Product dummies & No & No & Yes \\
\hline \multirow[t]{2}{*}{ Sample } & Group A & Group A & Group A \\
\hline & (7) & (8) & (9) \\
\hline Variables & $\begin{array}{c}\text { Inc } \\
\text { RevPerEmp }\end{array}$ & $\begin{array}{c}\text { Inc } \\
\text { RevPerEmp }\end{array}$ & $\begin{array}{c}\text { Inc } \\
\text { RevPerEmp }\end{array}$ \\
\hline \multirow[t]{2}{*}{ PercentOnline_A_20_40 } & $6,329^{*}$ & 6,007 & $6,545^{\star}$ \\
\hline & $(3,217)$ & $(3,634)$ & $(3,748)$ \\
\hline \multirow[t]{2}{*}{ PercentOnline_A_40_60 } & 7,966 & 9,038 & 9,375 \\
\hline & $(5,310)$ & $(5,887)$ & $(6,065)$ \\
\hline \multirow[t]{2}{*}{ PercentOnline_A_60_80 } & $10,169^{* *}$ & $10,541^{\star *}$ & $9,180^{\star \star}$ \\
\hline & $(4,054)$ & $(4,122)$ & $(3,905)$ \\
\hline \multirow[t]{2}{*}{ PercentOnline_A_80_100 } & $20,295^{\text {***}}$ & $20,836^{\star \star \star}$ & $21,309^{\star \star \star}$ \\
\hline & $(3,249)$ & $(3,473)$ & $(3,745)$ \\
\hline \multirow[t]{2}{*}{ PriorEmp_A } & 143.9 & 119.9 & 97.08 \\
\hline & $(241.2)$ & $(232.4)$ & (271.5) \\
\hline \multirow[t]{2}{*}{ YearsInOperation_A } & 55.86 & 17.35 & 194.2 \\
\hline & $(154.6)$ & $(171.0)$ & $(234.8)$ \\
\hline \multirow[t]{2}{*}{ Age } & 68.36 & 35.70 & -5.682 \\
\hline & $(209.7)$ & (206.6) & (221.7) \\
\hline
\end{tabular}




\begin{tabular}{|c|c|c|c|}
\hline & (7) & (8) & (9) \\
\hline Variables & $\begin{array}{c}\text { Inc } \\
\text { RevPerEmp }\end{array}$ & $\begin{array}{c}\text { Inc } \\
\text { RevPerEmp }\end{array}$ & $\begin{array}{c}\text { Inc } \\
\text { RevPerEmp }\end{array}$ \\
\hline \multirow[t]{2}{*}{ Male } & 1,218 & 901.3 & 1,684 \\
\hline & $(2,523)$ & $(2,767)$ & $(2,893)$ \\
\hline \multirow[t]{2}{*}{ RC_Education = 2, High school } & 2,988 & 7,432 & 10,498 \\
\hline & $(6,483)$ & $(6,888)$ & $(6,600)$ \\
\hline \multirow[t]{2}{*}{ RC_Education = 3, Vocational } & 3,290 & 3,263 & 5,822 \\
\hline & $(4,078)$ & $(5,307)$ & $(6,100)$ \\
\hline \multirow[t]{2}{*}{ RC_Education = 4, Bachelor } & 5,310 & 9,169 & 10,761 \\
\hline & $(5,943)$ & $(6,722)$ & $(6,461)$ \\
\hline \multirow{2}{*}{$\begin{array}{l}\text { RC_Education }=5 \text {, } \\
\text { Advanced degree }\end{array}$} & 1,778 & 4,972 & 4,719 \\
\hline & $(4,234)$ & $(4,847)$ & $(4,500)$ \\
\hline \multirow[t]{2}{*}{ ExtPressure_W } & $-1,545$ & $-1,198$ & 610.5 \\
\hline & $(1,999)$ & $(2,065)$ & $(2,169)$ \\
\hline \multirow[t]{2}{*}{ Constant } & $-4,664$ & 3,701 & $14,090^{* *}$ \\
\hline & $(4,260)$ & $(6,153)$ & $(6,177)$ \\
\hline Observations & 2,043 & 2,043 & 1,992 \\
\hline R-squared & 0.010 & 0.048 & 0.068 \\
\hline Province dummies & No & Yes & Yes \\
\hline Product dummies & No & No & Yes \\
\hline Sample & Group A & Group A & Group A \\
\hline
\end{tabular}

${ }^{* * *} p<0.01$

** $p<0.05$

${ }^{\star} p<0.1$

Notes: PercentOnline_A_20_40 is a binary variable that takes the value of 1 for Group A sellers who generate 20-40 per cent of total sales from online channels; YearsInOperation_A represents the age of the firm in years; ExtPressure_W is a binary variable that takes the value of 1 if the seller cited external pressure as a motivation to join e-commerce and 0 otherwise. Robust standard errors are in parentheses.

Columns (4) to (6) display the results for change in profit growth. The results reveal that SMEs with more than 20 per cent of their business online experienced a larger increase in profit growth. Specifically, the SMEs that had 20-40 per cent of their business online experienced a 2.6-2.7 percentage point higher increase in profit growth compared with the base group (sellers with at most 20 per cent of their business online). SMEs with 40-60 per cent online, $60-80$ per cent online and 80-100 per cent online experienced a 3.7-3.8, 6.7-6.9 and 4.6-4.7 
percentage point higher increase in profit growth, respectively, than the base group. Interestingly, for most groups, the higher the degree of digital integration, the higher was the increase in profit growth, except for the last group (80-100 per cent online), in which the increased profit growth became slightly lower. The longer the SMEs have been in operation, the lower is the increase in profit growth. Specifically, an additional year of operation is associated with a 0.03 percentage point lower increase in profit growth. Older sellers appeared to be doing worse than their younger peers (about 0.03 to 0.04 percentage points lower for an additional year of age). For some specifications, those who went online due to external pressure appeared to have a higher increase in profit growth (about 0.8 to 0.9 percentage point higher), but the results are only slightly significant.

Columns (7) to (9) display the results for increased efficiency (change in revenue per employment before versus after the seller went online). For all specifications, the SMEs with a high online presence (60 per cent or higher) are associated with a larger increase in efficiency. Specifically, SMEs with $60-80$ per cent and $80-100$ per cent of their business online experienced a THB9,180-10,541 and THB20,295-21,309 per person higher value in terms of increased efficiency, respectively, compared with the base group. (Note that for the $20-40$ per cent group, the significance is only minor and not robust across all specifications.)

In terms of increased efficiency, one may be concerned that efficiency comes at the cost of a reduction in employment. Table 5.5 addressed this concern, revealing changes in employment of Group A sellers after they went online. Only 8.8 per cent reported a decrease in employment. The majority (72.3 per cent) did not have any change in employment, whereas 18.9 per cent reported an increase in employment.

Table 5.5 Change in employment after adopting e-commerce (Group A)

\begin{tabular}{|l|r|r|}
\hline \multirow{2}{*}{ Change in employment } & \multicolumn{2}{|c|}{ Group A } \\
\cline { 2 - 3 } & \multicolumn{1}{|c|}{ Freq. } & \multicolumn{1}{c|}{$\%$} \\
\hline Decrease in employment & 180 & 8.8 \\
\hline No change & 1,482 & 72.3 \\
\hline Increase in employment & 387 & 18.9 \\
\hline Total & $\mathbf{2 , 0 4 9}$ & $\mathbf{1 0 0 . 0}$ \\
\hline
\end{tabular}


Recall from our discussion regarding Table 5.1 that Group A sellers' characteristics are similar to those of Thailand's small enterprises operating in the wholesale and retail sector as a whole. Although we cannot claim that our data sample represents the population of Thai SMEs, we may consider the results as what could have happened to the small enterprises operating in the wholesale and retail sector. However, as already mentioned, due to data limitations, we were not able to examine and compare the results for the traditional sellers who did not go online. We cannot exclude the possibility that the SMEs that went online are the more able ones and thus our results could be overestimated. We note this as a limitation of our study and encourage future research to revisit this issue once the required data are available.

\section{Economic analysis for new entrepreneurs (Group B)}

For Group B, the sellers started online and did not have an offline business, ${ }^{9}$ therefore, we were only able to gather the data for their current business. For the empirical analysis, we are not able to compare their business before they went online with after they went online in the same way as we analysed Group A.

Recall from our discussion regarding Table 5.1 that Group B sellers are much smaller than the average for Thailand's SMEs. Our interest here is to examine whether these smaller or individual sellers in Group B have augmented their household income by selling online. For this group, we will use logistical regressions to assess whether certain attributes of their online business are associated with any increase in their household income.

The empirical model used for the analysis is Equation 5.2.

\section{Equation 5.2}

$y_{i}=\alpha+\beta \cdot x_{i}+\theta_{p}+\gamma_{c}+\varepsilon_{i}$

In Equation 5.2, $y_{i}$ represents the dependent variable of seller $i$ that takes the value of 1 if the seller reported an increase in household income and 0 otherwise; $x_{i}$ is a vector of observable characteristics of seller is business. The key variables of interest are current revenue, current employment, years online (in this case, the same as years in operation) and whether

\footnotetext{
9 Very few of them may have set up an offline business later on.
} 
the seller is the primary earner in their household. In the equation, $\theta_{p}$ is the province dummy; $\gamma_{c}$ is the main product category dummy; and $\varepsilon_{i}$ is the error term. We use the robust standard errors clustered by province. We run three regressions - the first (the base analysis) has neither the province nor the product category dummies, the second has the province dummies but no product category dummies and the last has both the province dummies and the product category dummies.

The results are shown in Table 5.6. Columns (1) to (3) report the results of the base analysis and the augmented analyses, respectively. The results reveal that having high revenue and high employment (proxied for the size of the business) are associated with an increase in household income. The increase is also more likely if the sellers are the primary earners in their household.

Table 5.6 Impact on sellers (Group B)

\begin{tabular}{|l|r|r|r|}
\hline \multirow{2}{*}{ Variables } & \multicolumn{1}{|c|}{$(\mathbf{1})$} & (2) & \multicolumn{1}{c|}{ (3) } \\
\hline Ln_CurrentRev_B & IncreaseHHInc & IncreaseHHInc & IncreaseHHInc \\
\cline { 2 - 4 } & $0.391^{\star \star \star}$ & $0.401^{\star \star \star}$ & $0.395^{\star \star \star}$ \\
\hline CurrentEmp & $(0.0197)$ & $(0.0225)$ & $(0.0208)$ \\
\cline { 2 - 4 } & $0.0992^{\star \star \star}$ & $0.104^{\star \star \star}$ & $0.114^{\star \star \star}$ \\
\hline YearsOnline & $(0.0268)$ & $(0.0272)$ & $(0.0268)$ \\
\hline PrimaryEarner & -0.00404 & -0.00853 & -0.00919 \\
\cline { 2 - 5 } & $(0.0103)$ & $(0.0105)$ & $(0.0110)$ \\
\hline Constant & $0.540^{\star \star \star}$ & $0.558^{\star \star \star}$ & $0.542^{\star \star \star}$ \\
\hline Observations & $(0.0688)$ & $(0.0646)$ & $(0.0701)$ \\
\hline R-squared & $-2.694^{\star \star \star}$ & $-3.136^{\star \star \star}$ & $-2.372^{\star \star}$ \\
\hline Province dummies & $(0.115)$ & $(0.181)$ & $(0.966)$ \\
\hline Product dummies & 4,763 & 4,747 & 4,651 \\
\hline Sample & 0.133 & 0.148 & 0.149 \\
\hline
\end{tabular}

${ }^{* \star *} p<0.01$

${ }^{* *} p<0.05$

${ }^{*} p<0.1$

Note: Robust standard errors are in parentheses. 


\section{Connectivity analysis: E-commerce's role in increasing market discovery}

In this section, we examine how e-commerce can help existing SMEs (Group A) discover new market opportunities through two main potential mechanisms:

- Reducing geographical barriers: Through e-commerce, buyers are able to discover new products from distant provinces and regions more easily, in part due to reduced search costs. Sellers are also able to find new markets that they could not access in the past-for instance, through lower marketing costs and greater economies of scale in logistics.

- Reducing information asymmetry: Services on e-commerce platforms such as functions for chatting, payments (for example, escrow) and data analytics can help reduce information asymmetry and improve trust among buyers and sellers, resulting in more efficient transactions.

\section{Trade connections defined}

As already mentioned, in our survey, we asked our Group A sellers about the location of the customers to whom they sell (prior to going online versus the current period). Specifically, we asked respondents to select the regions to which they sell products, with eight options representing the various regions in Thailand. ${ }^{10}$ Due to the potential sensitivity of this question, we did not ask sellers about the value of sales to each region. As such, we only know whether the seller sells to a particular region or to their own province, but not the value of sales.

A 'trade connection' exists if the seller indicates they sell to a particular region in our survey. For instance, if a seller based in Bangkok selects the province of their residence, North Thailand and Northeast Thailand, we define this seller as having three trade connections. ${ }^{11}$ We asked the sellers

10 These options are: 1) province of own residence, 2) Bangkok, 3) other provinces in north Thailand, 4) other provinces in northeast Thailand, 5) other provinces in east Thailand, 6) other provinces in south Thailand, 7) other provinces in west Thailand and 8) provinces in central Thailand.

11 For sellers from Bangkok who selected both 'Bangkok' and 'province of own residence', we kept just one option. 
for data for two periods: before the seller went online and the current period. Changes in responses for these periods are used to determine the impact of e-commerce on trade connectivity.

The survey shows total trade connections increased materially after sellers adopted e-commerce. This increase was driven almost exclusively by trade outside the seller's region. The number of trade connections roughly doubled after sellers went online, rising from 4,400 to 8,600. In addition, the average number of trade connections per seller increased from 2.1 to 4.2 -that is, entrepreneurs in Thailand sold to two more regions, on average, after utilising e-commerce. The maps in Figure 5.1 show how trade intensity has risen across Thailand, before and after going online, while Figure 5.2 shows how trade has changed before and after e-commerce separately for Thailand's regions. Figures 5.3 and 5.4 show how the increase in trade connections was driven by an increase in activity outside the seller's own region.

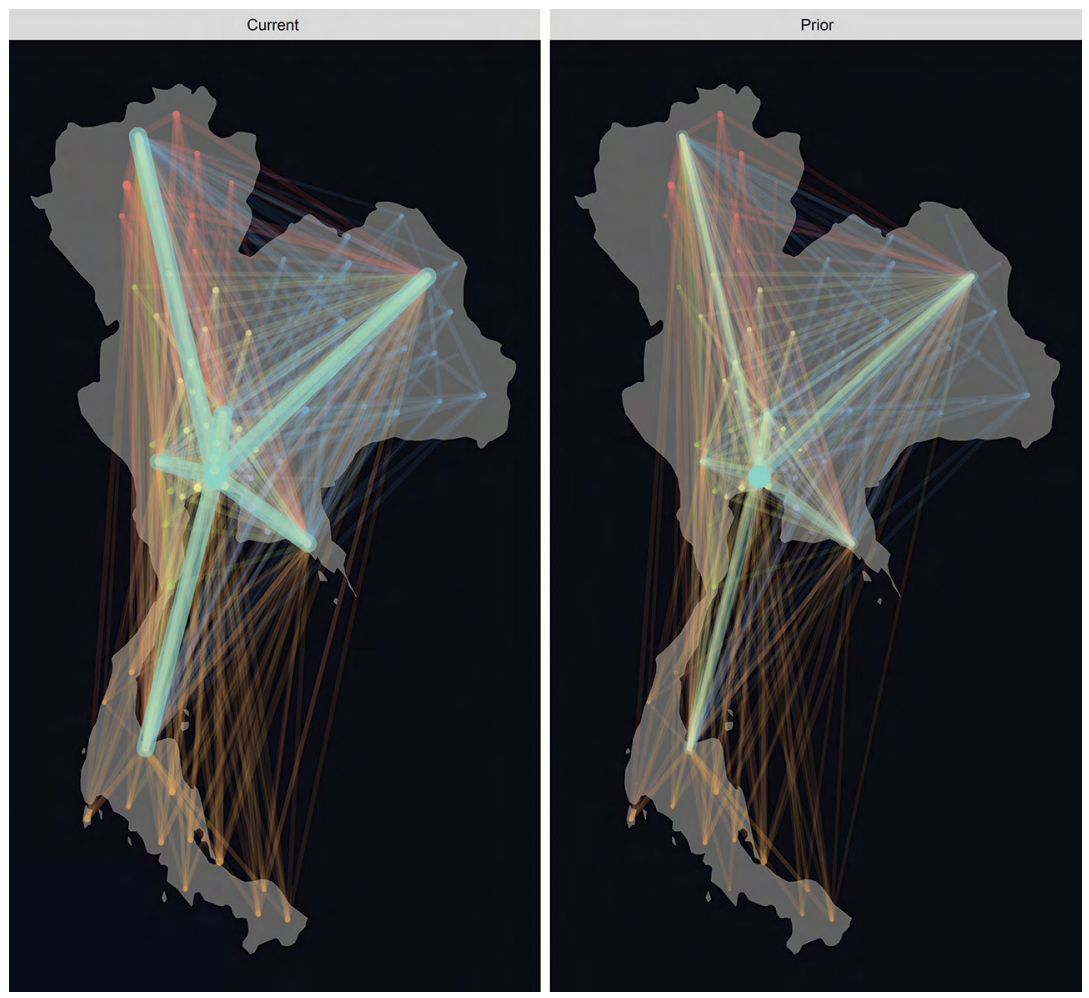

Figure 5.1 Increase in trade connections: Whole of Thailand

Source: Prepared by the authors based on the survey data. 

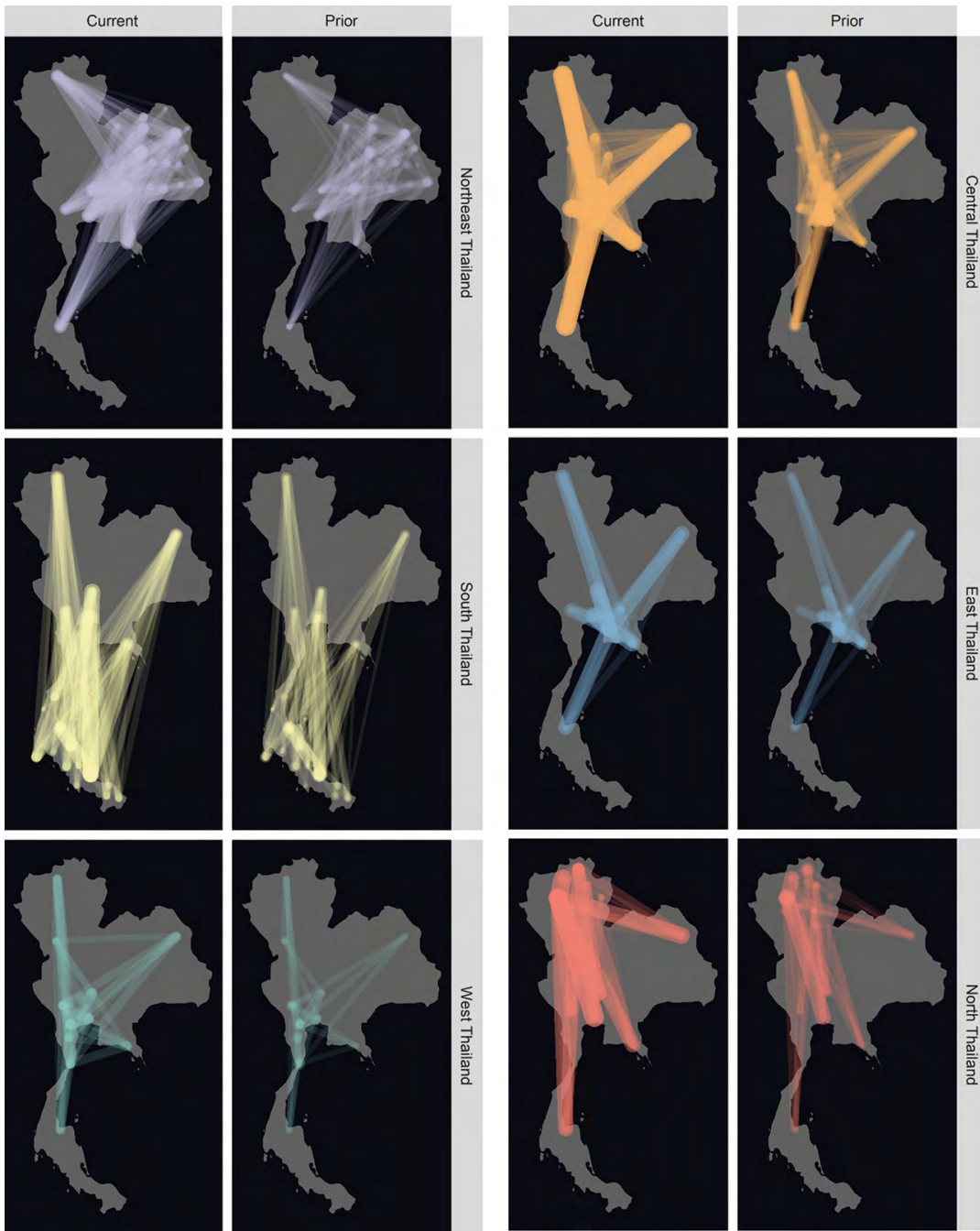

Figure $\mathbf{5 . 2}$ Increase in trade connections by region in Thailand

Source: Prepared by the authors based on the survey data. 


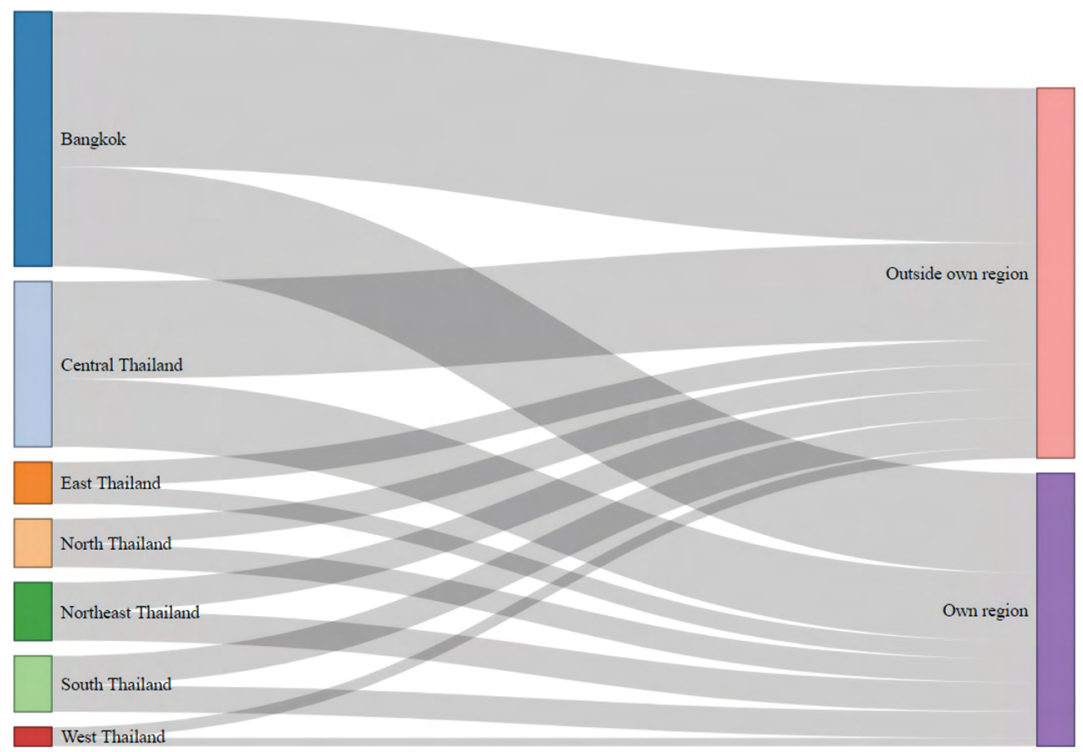

Figure 5.3 Sankey diagram: Own region versus outside own regionbefore e-commerce

Source: Prepared by the authors based on the survey data.

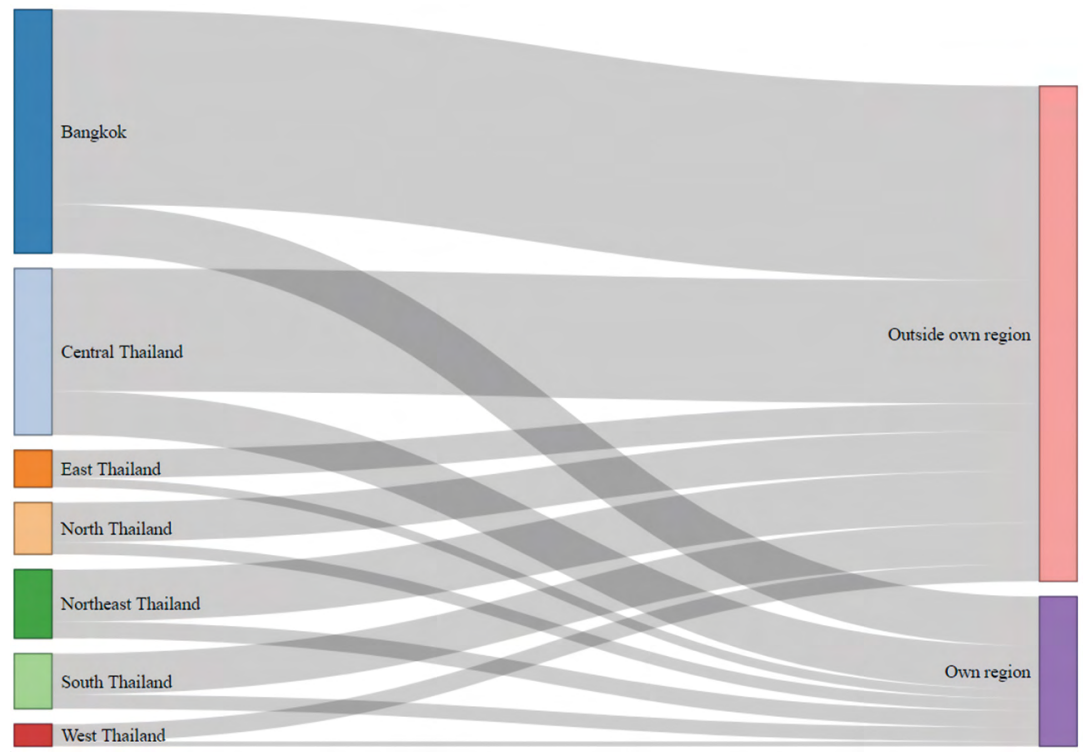

Figure 5.4 Sankey diagram: Own region versus outside own regionafter e-commerce

Source: Prepared by the authors based on the survey data. 


\section{Extensive versus intensive margins}

To examine the trade connections in detail, we first defined extraregional sellers (ERS) as sellers who sell goods outside their own geographic region. We then tried to capture the increased trade connections from two aspects:

1. Extensive margin-the new ERS: The extensive margin can be measured by the increase in trade connections by sellers who were not originally ERS and then became ERS after going online.

2. Intensive margin-preexisting ERS: The intensive margin can be measured by the increase in trade connections by sellers who were ERS and then sold to more regions after going online.

The increase in trade connections was driven much more by the 'new ERS' (extensive margin) than by the 'preexisting ERS' (intensive margin). The extensive margin accounted for around 76 per cent of the increase in trade connections for Thai sellers after moving online. The rest of the increase in trade connections was due to the intensive margin (24 per cent) (see Figure 5.5 for a waterfall chart decomposing the change in trade connections to the extensive and intensive margins). Figure 5.6 shows the share of trade connection increase based on extensive versus intensive margins.

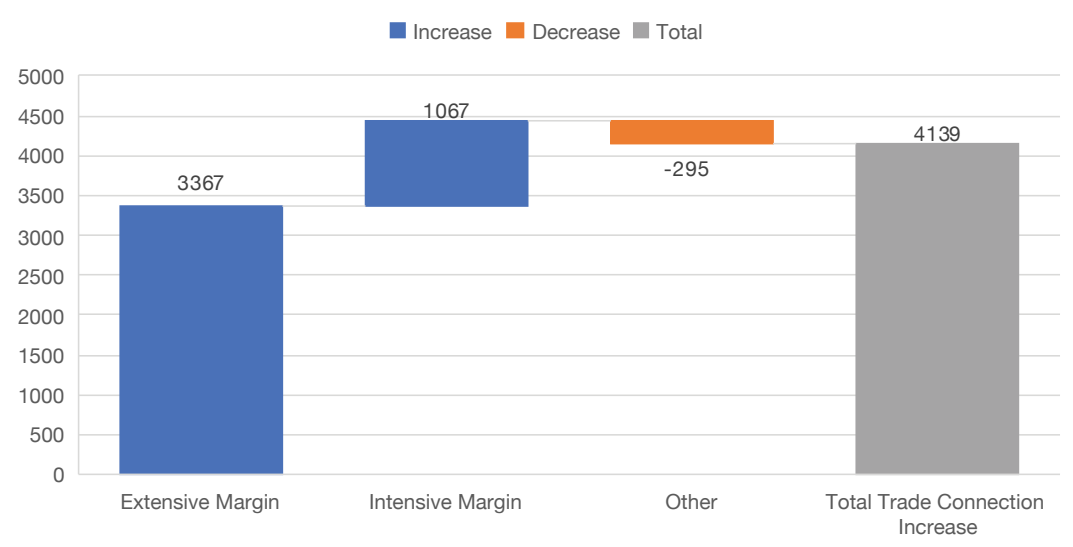

Figure 5.5 Waterfall chart: Decomposing into extensive versus intensive margins

Source: Prepared by the authors based on the survey data. 


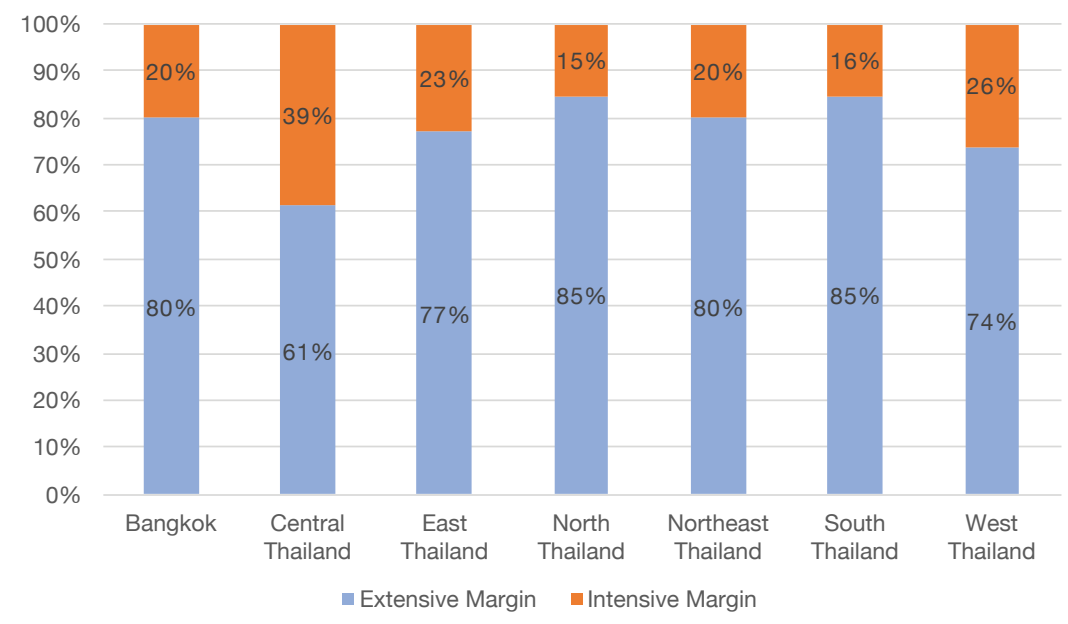

Figure 5.6 Share of trade connection increase based on extensive versus intensive margins

Source: Prepared by the authors based on the survey data.

Another way to look at the extensive margin is from the seller's perspective. Before moving online, around 44 per cent of sellers in Thailand sold outside their own region. After moving online, close to 81 per cent of sellers in Thailand are now selling outside their own region (see Table 5.7 for more details).

Table 5.7 Share of sellers selling outside own region (per cent)

\begin{tabular}{|l|r|r|r|}
\hline \multirow{2}{*}{ Location of seller } & \multicolumn{3}{|c|}{ Share of sellers selling outside own region } \\
\cline { 2 - 4 } & $\begin{array}{c}\text { Before moving } \\
\text { online }\end{array}$ & $\begin{array}{c}\text { Current } \\
\text { period }\end{array}$ & $\begin{array}{c}\text { Change in } \\
\text { share (pp) }\end{array}$ \\
\hline Bangkok & 37.92 & 71.86 & 33.94 \\
\hline Central Thailand & 57.17 & 86.87 & 29.70 \\
\hline East Thailand & 49.23 & 86.15 & 36.92 \\
\hline North Thailand & 44.10 & 91.93 & 47.83 \\
\hline Northeast Thailand & 41.18 & 85.78 & 44.61 \\
\hline South Thailand & 38.41 & 84.76 & 46.34 \\
\hline West Thailand & 47.76 & 86.57 & 38.81 \\
\hline Whole of Thailand & 44.46 & 80.87 & 36.41 \\
\hline
\end{tabular}




\section{Market discovery}

The largest increase in trade connectivity and market discovery after moving to e-commerce was for sellers in upcountry areas such as north and northeast Thailand, which are the two poorest regions. ${ }^{12}$

For instance, the shares of sellers in the north and northeast selling outside their own region increased by 48 percentage points and 45 percentage points, respectively-higher than the nationwide increase of 36 percentage points (see Table 5.7). Sellers in the north and northeast were also among the top three regions seeing the largest increase in average trade connections per seller, at 2.3 and 2.6, respectively (see Table 5.8). For the northern sellers, 85 per cent of the expansion in trade connections came from extensive margins (high counts of ERS) versus only 61 per cent for merchants in central Thailand.

Table 5.8 Average number of trade connections

\begin{tabular}{|l|r|r|r|}
\hline \multirow{2}{*}{ Location of seller } & \multicolumn{3}{|c|}{ Average number of trade connections } \\
\cline { 2 - 4 } & $\begin{array}{c}\text { Before moving } \\
\text { online }\end{array}$ & $\begin{array}{c}\text { Current } \\
\text { period }\end{array}$ & \multicolumn{1}{c|}{ Increase } \\
\hline Bangkok & 2.16 & 3.98 & 1.82 \\
\hline Central Thailand & 2.21 & 4.47 & 2.26 \\
\hline East Thailand & 2.12 & 3.78 & 1.66 \\
\hline North Thailand & 1.98 & 4.28 & 2.30 \\
\hline Northeast Thailand & 1.88 & 4.48 & 2.60 \\
\hline South Thailand & 2.26 & 4.48 & 2.22 \\
\hline West Thailand & 1.88 & 4.39 & 2.51 \\
\hline Whole of Thailand & 2.12 & 4.21 & 2.09 \\
\hline
\end{tabular}

This is important as it points to the possibility that e-commerce could help increase the reach of merchants who need the connections mostthose from the more remote and poorer regions. While we cannot establish causality from our analyses, it is interesting to note that the north and northeast saw the largest proportions of sellers reporting an increase in household income after adopting e-commerce: 86.1 per cent of merchants in the north and 83.8 per cent in the northeast reported an increase in household income after going online, both of which are higher than the nationwide average of 82.4 per cent (see Figure 5.7 and Table 5.9 for the data by region).

12 Based on the latest GDP per capita data (2016). 


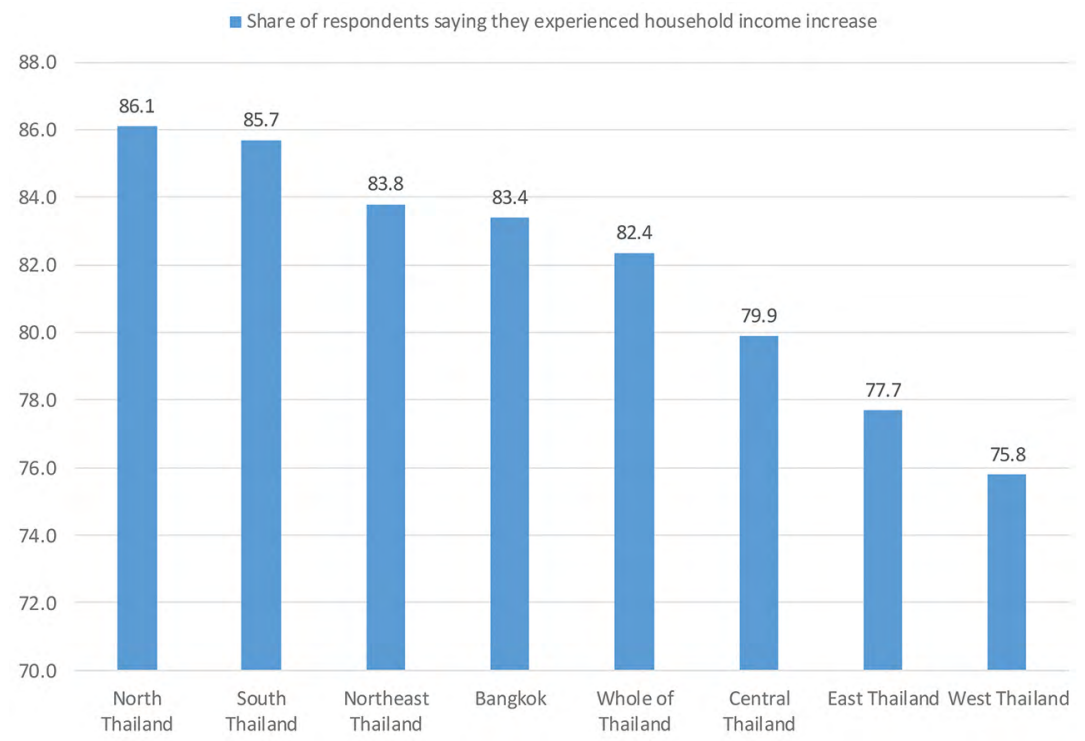

Figure 5.7 Impact on household income from e-commerce by region

Source: Prepared by the authors based on the survey data.

Table 5.9 Share of households reporting an increase in income, by region (per cent)

\begin{tabular}{|l|r|r|r|}
\hline \multirow{2}{*}{ Location of seller } & \multicolumn{3}{|c|}{$\begin{array}{c}\text { Percentage of households that report } \\
\text { an increase in income }\end{array}$} \\
\cline { 2 - 4 } & Group A & Group B & Whole sample \\
\hline Bangkok & 83.4 & 64.6 & 69.6 \\
\hline Central Thailand & 79.9 & 69.8 & 72.8 \\
\hline East Thailand & 77.7 & 67.6 & 70.5 \\
\hline North Thailand & 86.1 & 72.0 & 76.6 \\
\hline Northeast Thailand & 83.8 & 70.7 & 75.5 \\
\hline South Thailand & 85.7 & 70.8 & 76.9 \\
\hline West Thailand & 75.8 & 72.9 & 73.9 \\
\hline Whole of Thailand & 82.4 & 67.5 & 72.0 \\
\hline
\end{tabular}




\section{Discussions}

Our analyses show that e-commerce can help improve merchants' household income: 72 per cent of sellers reported an increase in income due to e-commerce, while 16.3 per cent reported significant improvement in household earnings. The improvement in income potentially works through different mechanisms for existing SMEs and new entrepreneurs.

\section{Existing SMEs (Group A)}

For existing SMEs, e-commerce empowers the business, raising profitability by lifting sales and improving efficiency. Generally, our models suggest the higher the degree of digital integration-measured by the share of e-commerce in the total business-the stronger are the benefits of e-commerce. Due to data limitations, we were unable to estimate the potential shift in the level of profits after merchants go online. But the significant jump in revenue and efficiency gains could indicate improvement in the level of profit. On average, merchants experienced a 163.4 per cent boost to revenue by going online, and could attain as much as a 284.6 per cent rise in sales if their degree of digital integration reached $80-100$ per cent. The surge in revenue came with improvement in efficiency-here measured as revenue per employee. In addition, we showed that, for most sellers, such increased efficiency did not come at a cost of reduction in employment.

Moreover, our analyses point to the potential improvement in profitability that goes beyond a one-off level shift. We found that merchants experience acceleration in profit growth as the share of e-commerce in total sales rises, with the benefit peaking at 6.9 per cent when the ratio hits $60-80$ per cent. This implies that digital integration may provide more than just a static boost to business performance, but also a more dynamic improvement. Perhaps the rise in the share of online sales indicates that firms are going through broader and/or deeper digital transformation (for example, digitisation of business processes) that brings about longerlasting efficiency gains.

Our connectivity analysis provides important clues to why such a boost to revenue is possible. E-commerce helps reduce the 'distance' between sellers and buyers resulting in market discovery beyond their immediate location. On average, businesses saw their number of trade connections 
double after moving online. This is predominantly through extensive margins - the share of sellers who sell to customers outside their own region rose from 44 per cent to 81 per cent after going online. But those who were already selling outside their own region also expanded the number of destinations.

Interestingly, we found that the poorest regions in Thailand, the north and northeast, experienced the greatest increase in trade connections after sellers adopted e-commerce. Note that these two regions also contain among the highest shares of households reporting an improvement in income due to e-commerce. This points to the possibility that e-commerce can be utilised to develop more remote and lower-income regions, contributing to more inclusive economic growth.

The basic characteristics of Group A sellers resemble those of all Thailand's small enterprises operating in the wholesale and retail sector; however, we cannot claim they are truly representative of the population. Due to data limitations, we were not able to examine traditional sellers who had not moved online. We note this as a limitation of our study and would like to leave this for future research to explore once the necessary data are available.

\section{New entrepreneurs (Group B)}

For the new entrepreneurs, we found that e-commerce could provide a source of additional income. In addition, the larger the sales and the number of employees, the better was the probability that the sellers experienced higher household income. The evidence is strengthened in the case where the sellers are the primary earner in their household.

The basic characteristics of Group B sellers are not similar to the average characteristics of all Thailand's SMEs. In fact, Group B sellers are much smaller in terms of sales and number of employees. The authors conjecture that these sellers may be operating as sole proprietors or individuals trying to supplement their income by selling items online. Our empirical results revealed that the more they can sell online the better chance they have of increasing their household income. 


\section{E-commerce: Different strokes for different folks}

There is also evidence suggesting that these new entrepreneurs (Group B sellers) are using e-commerce as a means of supplementing their income rather than it being the main business for the household.

According to our data, the majority of Group B sellers are people with other full-time responsibilities. The shares of people with full-time employment or who are homemakers in Group B are twice those in Group A. The share of students is three times higher in Group B than Group A. Second, these new entrepreneurs (Group B sellers) use profits from their business in a different way to those in the existing SMEs (Group A sellers) (see Table 5.10 for details). When asked what their profits are used for, 60.6 per cent of respondents from Group B indicated they were used for 'personal reasons', including saving, caring for family and education. Existing SMEs, on the other hand, have a higher tendency to use the profits for business purposes such as reinvestment and hiring staff. Third, the two groups have different motives for adopting e-commerce (see Table 5.11 for details). When asked about their motivations to participate in e-commerce, 59.9 per cent of respondents from Group B nominated 'personal reasons' - quality of life, convenience, flexibility and so on-while only 40.1 per cent mentioned business motivations including cutting costs or business expansion. For Group A, the numbers are 53.2 per cent for personal reasons and 46.8 per cent for businessrelated purposes. In addition, the majority of Group B sellers are people with other full-time jobs.

Table 5.10 Use of profits

\begin{tabular}{|l|r|r|r|r|}
\hline & \multicolumn{1}{|c|}{$\begin{array}{c}\text { Personal } \\
\text { reasons }\end{array}$} & $\begin{array}{c}\text { Business } \\
\text { reasons }\end{array}$ & \multicolumn{1}{c|}{$\begin{array}{c}\text { Mixed } \\
\text { reasons }\end{array}$} & \multicolumn{1}{c|}{$\begin{array}{c}\text { Total } \\
\text { responses }\end{array}$} \\
\hline \multirow{2}{*}{ Group A } & 2,372 & 1,412 & 473 & \multirow{4}{4}{$\mathbf{4 , 3 5 7}$} \\
\cline { 2 - 4 } & $(55.7 \%)$ & $(33.2 \%)$ & $(11.1 \%)$ & \\
\cline { 2 - 4 } Group B & 5,295 & 2,700 & 741 & \multirow{2}{*}{$\mathbf{8 , 7 3 6}$} \\
\cline { 2 - 4 } & $(60.6 \%)$ & $(30.9 \%)$ & $(8.5 \%)$ & \\
\hline
\end{tabular}

Notes: Personal uses of profits include saving, paying for education and helping care for family. Business uses include reinvestment in the business, hiring more employees and increasing employees' salaries. Mixed reasons refer to using profits to repay outstanding loans, where it is not possible to determine whether the loan is personal or business-related. Respondents to this question were allowed to select multiple answers, with no minimum or maximum limit to the number of choices selected. Therefore, the total responses could be larger or smaller than the total number of respondents. 
Table 5.11 Motivation for entering into e-commerce

\begin{tabular}{|l|r|r|r|}
\hline & Personal reasons & Business reasons & Total responses \\
\hline \multirow{2}{*}{ Group A } & 4,334 & 3,812 & \multirow{2}{*}{$\mathbf{8 , 1 4 6}$} \\
\cline { 2 - 3 } & $(53.2 \%)$ & $(46.8 \%)$ & \\
\hline \multirow{2}{*}{ Group B } & 9,711 & 6,491 & \multirow{1}{*}{$\mathbf{1 6 , 2 0 2}$} \\
\cline { 2 - 3 } & $(59.9 \%)$ & $(40.1 \%)$ & \\
\hline
\end{tabular}

Notes: Personal motivations include ease of online shop setup, flexibility of working hours, greater time for household work, shorter commute and better quality of life. Business motivations include the ability to expand the business, lowering business costs, external pressure (for example, other companies going online), financial security and to reduce business risk. Respondents to this question were allowed to select multiple answers, with no minimum or maximum limit to the number of choices selected. Therefore, the total responses could be larger or smaller than the total number of respondents.

\section{Conclusions and policy implications}

Using unique and large-scale survey data on merchants in Thailand, this chapter found that e-commerce adoption can result in improvement in household incomes for sellers. In particular, by reducing distance, time and cost constraints, e-commerce can result in two types of benefit. First, e-commerce empowers existing SMEs by significantly boosting their revenue, efficiency and profit growth. The improvement in profitability seems to go beyond a one-off gain as going online also results in stronger profit growth rates. Second, our trade connectivity analysis illustrates how e-commerce allows merchants, especially those in poorer regions, to discover new market opportunities outside their own region. In addition, e-commerce allows people of various employment status-including fulltime employees, homemakers and students-to earn additional income, while maintaining other responsibilities.

While existing SMEs have a greater tendency to reinvest additional profits in their business, part-time entrepreneurs are more likely to use their extra earnings to care for family and pay for education. Our research also points to the possibility that e-commerce could help spread development to remote areas such as upcountry in the north and northeast of Thailand. Connectivity analyses showed that these two poorest regions saw the largest boost to trade connectivity and were among the top regions to report improvement in household income after e-commerce adoption. 
Our study is, however, subject to certain limitations. Since our survey was voluntary, we need to find a balance between the information we would like to get and the information the respondents were willing to provide. First, we were not able to build a panel dataset. We were only able to ask the sellers about their current situation (now they were online) and their previous situation (when they were not online or when they were just starting off). This information allowed us to visualise the impact, although not as accurately as if we were able to construct a panel dataset. Second, sellers may consider some information sensitive, so we avoided asking about it; however, we tried to ask the 'second-best' questions. For example, we avoided asking sellers about actual profit and instead asked about profit growth. Third, we were only able to analyse the sellers who had engaged in e-commerce and not those who are yet to go online to compare the results. We note all these as limitations of our current work and encourage future research to revisit this issue once the appropriate data are available.

However, it is still undeniable that e-commerce can potentially serve as a tool to contribute to economic growth, by empowering SMEs, new entrepreneurs and those in more remote areas. This is particularly important for emerging markets such as ASEAN member states, where 99 per cent of enterprises are SMEs (Bain \& Company 2018) and urbanisation is relatively low at only 51 per cent compared, for example, with 85 per cent in Latin America (UN 2019). E-commerce adoption by entrepreneurs is by no means automatic. To fully unlock the potential of e-commerce, governments and the private sector need to work together to address two types of constraints entrepreneurs face to selling online: those that prevent the adoption of e-commerce, such as limited internet access and lack of digital skills, and those that hold back the effectiveness of e-commerce, including underdeveloped logistics, payment systems and regulatory environments (World Bank 2019).

\section{Promoting e-commerce adoption}

We observed from our results that existing businesses gained by going online in terms of increases in revenue, profit growth and efficiency. In addition, individuals can also earn extra income by selling online that could increase their total household income. Therefore, promoting e-commerce adoption should be a key recommendation for policymakers. This can be achieved in two ways: increased digital access and increased digital literacy. 
In terms of increasing digital access, the Thai Government implemented the Village Broadband Internet Project (Net Pracharat) in 2017, through which it provided free broadband internet to 24,700 rural villages throughout the country. In 2018, Thailand's internet penetration rate was 82 per cent (Kemp 2019a). In addition, Thailand's mobile broadband connectivity (mobile broadband connections per population) is 133 per cent, which is higher than the global average of 74 per cent.

Improving internet access through better digital infrastructure is essential but not sufficient. According to Bain \& Company (2018), although 75 per cent of ASEAN SMEs see digital tools as an opportunity, only 16 per cent truly utilise them to their full potential. The same report found that 45 per cent of ASEAN SMEs lack an understanding of technology, while 40 per cent see a gap in digital skills (Bain \& Company 2018). The authors see this lack of digital literacy as the last-mile barrier to e-commerce adoption. Improving digital skills is crucial to ensure that the rapid growth in the digital economy is inclusive, benefiting everyone and not just those with the knowhow to unlock its potential.

Governments and the private sector can collaborate to provide relevant training for would-be online entrepreneurs. For instance, policymakers can work with e-commerce platforms in the region to scale up offline training programs to teach SMEs how to sell online. Partnerships between academia and industry are also crucial. Given how rapidly skillsets change, higher education institutions should partner with private institutions to adjust their curriculums to ensure what is taught in the lecture theatre is relevant to industry.

\section{Enhancing the effectiveness of e-commerce}

Although the sellers in our sample who went online were able to discover new market opportunities, the benefits they could achieve are still limited by the effectiveness of e-commerce. Therefore, our policy recommendations would be to increase logistics efficiency, improve the regulatory environment and increase the adoption of digital payment systems.

The Thai Government has a crucial role to play in improving logistics infrastructure to reduce the costs of shipping items across the country. This goes beyond building hard infrastructure and includes improving the general regulatory environment for businesses such as by cutting red 
tape, streamlining approval processes and dismantling tariff and nontariff barriers. For example, Thailand's ongoing effort to use the Regulatory Guillotine and remove outdated laws is a step in the right direction.

Another key constraint on e-commerce growth is the lack of digital payment systems and a high reliance on cash on delivery in ASEAN countries. The good news is that governments across the region, including in Thailand, are already taking steps to improve the digital payments ecosystem through initiatives such as QR-code standardisation and enabling e-KYC (know-your-customer). The next steps for policymakers include promoting digital IDs and improving the interoperability of payment systems to promote efficiency.

\section{References}

Bain \& Company. 2018. Advancing towards ASEAN digital integration. Report. Boston: Bain \& Company.

Cheewatrakoolpong, K. and Mallikamas, S. 2019. บทบาทของ ต่อการค้าระหว่าง ประเทศ [The Role of E-Commerce in International Trade], [in Thai]. TRF Project. Bangkok: Thailand Research Fund.

Christopher, M. 2018. 'Thailand 4.0: The smart grid project.' OpenGov Asia, 20 July. Available from: www.opengovasia.com/thailand-4-0-the-smart-gridproject.

Couture, V., Faber, B., Gu, Y. and Liu, L. 2018. E-commerce integration and economic development: Evidence from China. NBER Working Paper No. w24384. Cambridge, MA: National Bureau of Economic Research.

Dai, R. and Zhang, X. 2016. E-commerce expands the bandwidth of entrepreneurship. Paper presented to American Economic Association Conference, San Francisco, CA, 3-5 January.

Dolfen, P., Einav, L., Klenow, P., Klopack, B., Levin, J., Levin, L. and Best, W. 2019. Assessing the gains from e-commerce. NBER Working Paper No. 25610. Cambridge, MA: National Bureau of Economic Research. doi.org/10.3386/ w25610.

ecommerceIQ. 2018. eIQ Consumer Pulse: Uncovering the value of Thailand's top online platforms. Bangkok: ecommerceIQ. 
Fan, J., Tang, L., Zhu, W. and Zou, B. 2018. 'The Alibaba effect: Spatial consumption inequality and the welfare gains from e-commerce.' Journal of InternationalEconomics 114:203-20. doi.org/10.1016/j.jinteco.2018.07.002.

Google and Temasek 2018. e-Conomy SEA 2018: Southeast Asia's internet economy hits an inflection point. 3rd edn. Singapore: Google Asia-Pacific.

Huang, B., Shaban, M., Song, Q. and Wu, Y. 2018. E-commerce development and entrepreneurship in the People's Republic of China. ADBI Working Paper Series No. 827. Tokyo: Asian Development Bank Institute.

Jones, C. and Pimdee, P. 2017. 'Innovative ideas: Thailand 4.0 and the fourth industrial revolution.' Asian International Journal of Social Science 17(1): 4-35.

Kemp, S. 2011. Digital 2011: Thailand. 28 December. New York: We Are Social Inc. Available from: datareportal.com/reports/digital-2011-thailand.

Kemp, S. 2019a. Digital 2019: Essential insights into how people around the world use the internet, mobile devices, social media, and e-commerce. New York: We Are Social Inc.

Kemp, S. 2019b. Digital 2019: Global internet use accelerates. Blog, 30 January. New York: We Are Social Inc. Available from: wearesocial.com/blog/2019/01/ digital-2019-global-internet-use-accelerates.

Lendle, A., Olarreaga, M., Schropp, S. and Vézina, P.L. 2016. 'There goes gravity: eBay and the death of distance.' The Economic Journal 126(591): 406-41. doi.org/10.1111/ecoj.12286.

McKinsey \& Company. 2018. The Digital Archipelago: How online commerce is driving Indonesia's economic development. New York: McKinsey \& Company.

Office of Small and Medium Enterprises Promotion (OSMEP). 2019. White Paper on SME. www.sme.go.th/upload/mod_download/download-20190919 092631.pdf.

Rowe, F., Truex, D. and Huynh, M.Q. 2012. 'An empirical study of determinants of e-commerce adoption in SMEs in Vietnam: An economy in transition.' Journal of Global Information Management 20(3): 23-54. doi.org/10.4018/ jgim.2012070102.

Royal Thai Embassy. n.d. Thailand 4.0: What is Thailand 4.0? Washington, DC: Royal Thai Embassy. Available from: thaiembdc.org/thailand-4-0-2.

Sathirathai, S. and Wan, M. 2018. 'ASEAN e-commerce: Hidden tigers meet tech dragons.' The Nation Thailand, 5 February. Available from: www.nation thailand.com/business/30338037. 
Sea and World Economic Forum (WEF). 2018. ASEAN Youth and the Future of Work. Singapore \& Bern: Sea Limited \& WEF.

Think with Google. 2017. Consumer Barometer. Mountainview, CA: Google. Available from: www.consumerbarometer.com/en/graph-builder/?question= N1\&filter=country:vietnam,indonesia,philippines, taiwan,thailand,singapore ,malaysia.

United Nations (UN). 2019. Population Dynamics: World population prospects 2019. New York: Department of Economic and Social Affairs. Available from: population.un.org/wpp.

United Nations Economic and Social Commission for Asia and the Pacific (UNESCAP) and Asian Development Bank (ADB). 2018. Embracing the E-Commerce Revolution in Asia and the Pacific. Bangkok: UNESCAP.

Wong, P.K. 2003. 'Global and national factors affecting e-commerce diffusion in Singapore.' The Information Society 19(1): 19-32. doi.org/ 10.1080/01972240309471.

World Bank. 2017. The Global Findex Database 2017. Washington, DC: World Bank Group. Available from: globalfindex.worldbank.org/node.

World Bank. 2019. The Digital Economy in Southeast Asia: Strengthening the foundations for future growth. Washington, DC: World Bank Group.

Worldpay. 2018. Global Payments Report. Jacksonville, FL: Worldpay from FIS.

\section{Appendices}

\section{Appendix 5.1 Survey questionnaire}

\begin{tabular}{|l|l|l|}
\hline \multicolumn{3}{|c|}{ Demographics } \\
\hline Questions and options & Type of variable \\
\hline 1. What is your gender? & F/M & $\begin{array}{l}\text { Date option in } \\
\text { SurveyGizmo }\end{array}$ \\
\hline 2. When were you born? & DD/MM/YYYY & $\begin{array}{l}\text { No schooling/Elementary/Junior high/Senior high/ } \\
\text { Vocational/Bachelor/Higher than Bachelor/Other }\end{array}$ \\
\hline $\begin{array}{l}\text { 3. What is the highest } \\
\text { level of education you } \\
\text { have attained? }\end{array}$ & $\begin{array}{l}\text { 4. Are you the primary } \\
\text { income earner of your } \\
\text { household? }\end{array}$ & Yes/No \\
\hline
\end{tabular}




\begin{tabular}{|c|c|c|}
\hline \multicolumn{3}{|c|}{ Demographics } \\
\hline \multicolumn{2}{|l|}{ Questions and options } & Type of variable \\
\hline $\begin{array}{l}\text { 5. How many people } \\
\text { are there in your } \\
\text { household? }\end{array}$ & Fill in: $\_$(number) & $\begin{array}{l}\text { From } 1 \text { to } \\
\text { maximum } 20\end{array}$ \\
\hline $\begin{array}{l}\text { 6. What is your current } \\
\text { employment status? }\end{array}$ & \multicolumn{2}{|c|}{$\begin{array}{l}\text { Employed full-time (35 hours/week or more)/Employed } \\
\text { part-time (less than } 35 \text { hours/week)/Self-employed or } \\
\text { Work for my own business/Unemployed-Looking for } \\
\text { work/Not employed-Student/Not employed-Doing } \\
\text { household work or taking care of dependents/Not } \\
\text { employed-Retired/Other (please specify) }\end{array}$} \\
\hline $\begin{array}{l}\text { 7. Is e-commerce your } \\
\text { primary source of } \\
\text { income? }\end{array}$ & \multicolumn{2}{|l|}{ Yes/No } \\
\hline $\begin{array}{l}\text { 8. What is your } \\
\text { estimated monthly } \\
\text { household income? }\end{array}$ & [See Appendix 5.2] & Dropdown option \\
\hline $\begin{array}{l}\text { 9. In which province are } \\
\text { you currently located? }\end{array}$ & [See Appendix 5.2] & Dropdown option \\
\hline $\begin{array}{l}\text { 10. When did you start } \\
\text { selling online? }\end{array}$ & DD/MM/YYYY & $\begin{array}{l}\text { Date option in } \\
\text { SurveyGizmo }\end{array}$ \\
\hline $\begin{array}{l}\text { 11. Do you have an } \\
\text { offline business? }\end{array}$ & Yes/No & \\
\hline \multicolumn{3}{|c|}{ If you answered 'Yes' to Question 11, go to Question 12} \\
\hline \multicolumn{3}{|c|}{ If you answered 'No' to Question 11, go to Question Group B } \\
\hline $\begin{array}{l}\text { 12. Did you start selling } \\
\text { offline before selling } \\
\text { online? }\end{array}$ & \multicolumn{2}{|l|}{ Yes/No } \\
\hline \multicolumn{3}{|c|}{ If you answered 'Yes' to Question 12, go to Question Group A } \\
\hline \multicolumn{3}{|c|}{ If you answered 'No' to Question 12, go to Question Group B } \\
\hline
\end{tabular}

\begin{tabular}{|c|c|c|}
\hline \multicolumn{3}{|c|}{ Economic and social impacts of e-commerce } \\
\hline \multicolumn{3}{|c|}{ Question group A (Traditional business goes online) } \\
\hline \multicolumn{2}{|l|}{ Questions and options } & Type of variable \\
\hline $\begin{array}{l}\text { 13. When did you start } \\
\text { selling offline? }\end{array}$ & DD/MM/YYYY & $\begin{array}{l}\text { Date option in } \\
\text { SurveyGizmo }\end{array}$ \\
\hline \multicolumn{3}{|c|}{ 14. Question about monthly sales of your business (online + offline): } \\
\hline $\begin{array}{l}\text { Currently, your business } \\
\text { has average sales per } \\
\text { month of: }\end{array}$ & [Local currency] & Number \\
\hline $\begin{array}{l}\text { Just before your business } \\
\text { went online, your business } \\
\text { had average sales per } \\
\text { month of: }\end{array}$ & [Local currency] & Number \\
\hline
\end{tabular}


Economic and social impacts of e-commerce

Question group A (Traditional business goes online)

Questions and options

Type of variable

15. Online sales as a percentage of total monthly sales of your business are currently:

Percentage: (0\% to $100 \%)$

Percentage: $0 \%$ to maximum $100 \%$

16. Question about the number of employees of your business:

\begin{tabular}{l|l|l|}
\hline $\begin{array}{l}\text { Currently, the number of } \\
\text { employees hired by your } \\
\text { business is: }\end{array}$ & Number & $\begin{array}{l}\text { No negative } \\
\text { number }\end{array}$ \\
\hline $\begin{array}{l}\text { Just before your business } \\
\text { went online, the number of } \\
\text { employees hired by your } \\
\text { business was: }\end{array}$ & Number & $\begin{array}{l}\text { No negative } \\
\text { number }\end{array}$ \\
\hline
\end{tabular}

17. Question about increasing profits of your business:

\begin{tabular}{|c|c|c|}
\hline $\begin{array}{l}\text { Currently, average profit } \\
\text { increases per year by: }\end{array}$ & $\begin{array}{l}\text { No increase/Increase by } 1-3 \% / \\
\text { Increase by } 4-6 \% / \text { Increase by } 7-9 \% / \\
\text { Increase by } 10-12 \% / \text { Increase by } 13- \\
15 \% / \text { Increase by } 16-18 \% / \text { Increase } \\
\text { by } 19-21 \% / \text { Increase by } 22-24 \% / \\
\text { Increase by } 25-27 \% / \text { Increase by } \\
28-30 \% / \text { Increase by more than } 30 \%\end{array}$ & Dropdown option \\
\hline $\begin{array}{l}\text { Just before your business } \\
\text { went online, average } \\
\text { profits increased per year } \\
\text { by: }\end{array}$ & $\begin{array}{l}\text { No increase/Increase by } 1-3 \% / \\
\text { Increase by } 4-6 \% / \text { Increase by } 7-9 \% / \\
\text { Increase by } 10-12 \% / \text { Increase by } 13- \\
15 \% / \text { Increase by } 16-18 \% / \text { Increase } \\
\text { by } 19-21 \% / \text { Increase by } 22-24 \% / \\
\text { Increase by } 25-27 \% / \text { Increase by } \\
28-30 \% / \text { Increase by more than } 30 \%\end{array}$ & Dropdown option \\
\hline \multicolumn{3}{|c|}{ 18. How has selling online changed your household income? } \\
\hline \multicolumn{3}{|c|}{$\begin{array}{l}\text { a) Increased significantly; b) Increased somewhat; c) Not much impact; d) Decreased } \\
\text { somewhat; e) Decreased significantly }\end{array}$} \\
\hline \multicolumn{3}{|c|}{ 19. From which regions do your customers come? } \\
\hline Currently & \multicolumn{2}{|l|}{ [See Appendix 5.2] } \\
\hline $\begin{array}{l}\text { Just before your business } \\
\text { went online }\end{array}$ & \multicolumn{2}{|l|}{ [See Appendix 5.2] } \\
\hline
\end{tabular}

\begin{tabular}{|l|l|l|}
\hline \multicolumn{2}{|c|}{ Economic and social impacts of e-commerce } \\
\hline \multicolumn{2}{|c|}{ Question group B (Businesses that launched online only) } \\
\hline Questions and options & Type of variable \\
\hline 13. Question about monthly sales of your business: & Number \\
\hline $\begin{array}{l}\text { Currently, your business } \\
\text { has sales revenue per } \\
\text { month of: }\end{array}$ & [Local currency] & \\
\hline
\end{tabular}


Economic and social impacts of e-commerce Question group B (Businesses that launched online only)

\begin{tabular}{|l|l|l|}
\hline \multicolumn{2}{|l|}{ Questions and options } & Type of variable \\
\hline $\begin{array}{l}\text { When you started your } \\
\text { online business, your } \\
\text { business had average } \\
\text { sales per month of: }\end{array}$ & [Local currency] & Number \\
\hline
\end{tabular}

\section{Question about the number of employees of your business:}

\begin{tabular}{l|l|l|}
\hline $\begin{array}{l}\text { Currently, the number of } \\
\text { employees hired by your } \\
\text { business is: }\end{array}$ & Number & $\begin{array}{l}\text { No negative } \\
\text { number }\end{array}$ \\
\hline $\begin{array}{l}\text { When you started your } \\
\text { online business, the } \\
\text { number of employees hired } \\
\text { by your business was: }\end{array}$ & Number & $\begin{array}{l}\text { No negative } \\
\text { number }\end{array}$ \\
\hline
\end{tabular}

\section{Question about increasing profits of your business:}

\begin{tabular}{|c|c|c|}
\hline $\begin{array}{l}\text { Currently, average profit } \\
\text { increases per year by: }\end{array}$ & $\begin{array}{l}\text { No increase/Increase by } 1-3 \% / \\
\text { Increase by } 4-6 \% / \text { Increase by } 7-9 \% / \\
\text { Increase by } 10-12 \% / \text { Increase by } 13- \\
15 \% / \text { Increase by } 16-18 \% / \text { Increase } \\
\text { by } 19-21 \% / \text { Increase by } 22-24 \% / \\
\text { Increase by } 25-27 \% / \text { Increase by } \\
28-30 \% / \text { Increase by more than } 30 \%\end{array}$ & Dropdown option \\
\hline $\begin{array}{l}\text { When you started your } \\
\text { online business, average } \\
\text { profits increased per year } \\
\text { by: }\end{array}$ & $\begin{array}{l}\text { No increase/Increase by } 1-3 \% / \\
\text { Increase by } 4-6 \% / \text { Increase by } 7-9 \% / \\
\text { Increase by } 10-12 \% / \text { Increase by } 13- \\
15 \% / \text { Increase by } 16-18 \% / \text { Increase } \\
\text { by } 19-21 \% / \text { Increase by } 22-24 \% / \\
\text { Increase by } 25-27 \% / \text { Increase by } \\
28-30 \% / \text { Increase by more than } 30 \%\end{array}$ & Dropdown option \\
\hline
\end{tabular}

16. How has selling online changed your household income?

a) Increased significantly; b) Increased somewhat; c) Not much impact; d) Decreased somewhat; e) Decreased significantly

\begin{tabular}{|l|l|}
\hline 17. From which regions do your customers come? \\
\hline Currently & [See Appendix 5.4] \\
\hline $\begin{array}{l}\text { When you started your } \\
\text { online business }\end{array}$ & [See Appendix 5.4] \\
\hline
\end{tabular}

\begin{tabular}{|l|l|}
\hline \multicolumn{2}{|c|}{$\begin{array}{l}\text { Motivations for entering e-commerce and criteria for choosing } \\
\text { e-commerce platform }\end{array}$} \\
\hline \multicolumn{2}{|c|}{ Continue from Question group A + B } \\
\hline Questions and options & Type of variable \\
\hline $\begin{array}{l}\text { 19. What are your main motivations for choosing to sell via e-commerce? } \\
\text { (Click all that apply) }\end{array}$ \\
\hline a) Ease of setting up an online business \\
\hline b) Flexibility and better work-life balance \\
\hline
\end{tabular}




\begin{tabular}{|c|c|}
\hline \multicolumn{2}{|c|}{$\begin{array}{l}\text { Motivations for entering e-commerce and criteria for choosing } \\
\text { e-commerce platform }\end{array}$} \\
\hline \multicolumn{2}{|c|}{ Continue from Question group A + B } \\
\hline Questions and options & Type of variable \\
\hline \multicolumn{2}{|c|}{ c) More time to handle household work and take care of children } \\
\hline \multicolumn{2}{|l|}{ d) Opportunity to expand the business } \\
\hline \multicolumn{2}{|l|}{ e) Lower cost of doing business } \\
\hline \multicolumn{2}{|l|}{ f) External pressure (others are doing it) } \\
\hline \multicolumn{2}{|l|}{ g) Shorter commute to work } \\
\hline \multicolumn{2}{|l|}{ h) Quality of life } \\
\hline \multicolumn{2}{|l|}{ i) Financial security } \\
\hline \multicolumn{2}{|l|}{ j) Reduced risks } \\
\hline \multicolumn{2}{|c|}{ 20. How do you use profits gained through e-commerce? (Click all that apply) } \\
\hline \multicolumn{2}{|c|}{ a) Reinvest into e-commerce business } \\
\hline \multicolumn{2}{|l|}{ b) Hire more employees } \\
\hline \multicolumn{2}{|l|}{ c) Increase employee salaries and/or benefits } \\
\hline \multicolumn{2}{|l|}{ d) Save the additional profits } \\
\hline \multicolumn{2}{|l|}{ e) Pay down loans (e.g., mortgage and car loans) } \\
\hline \multicolumn{2}{|l|}{ f) Pay for education } \\
\hline \multicolumn{2}{|c|}{ g) Care for family members (e.g., supporting dependants) } \\
\hline \multicolumn{2}{|l|}{ h) Other, please specify ___ } \\
\hline \multicolumn{2}{|c|}{$\begin{array}{l}\text { 21. How many platforms do you use to sell your goods? Include both } \\
\text { e-commerce and social media platforms. (Fill in the blanks) }\end{array}$} \\
\hline No. of platforms: & $\begin{array}{l}\text { No negative } \\
\text { number }\end{array}$ \\
\hline \multicolumn{2}{|c|}{$\begin{array}{l}\text { 22. Please rank the top-three platforms in terms of how good you think they } \\
\text { are (Rank } 1 \text { to } 3,1 \text { being the best) }\end{array}$} \\
\hline $\begin{array}{l}\text { Shopee } \\
\text { Lazada } \\
\text { JD Central } \\
\text { Instagram } \\
\text { Twitter } \\
\text { Facebook } \\
\end{array}$ & $\begin{array}{l}\text { Rank in } \\
\text { SurveyGizmo }\end{array}$ \\
\hline $\begin{array}{l}\text { 23. Please rank the five most important } c \\
\text { e-commerce platform on which to sell. ( } R\end{array}$ & $\begin{array}{l}\text { ring an } \\
\text { he best) }\end{array}$ \\
\hline
\end{tabular}




\begin{tabular}{|l|l|}
\hline \multicolumn{2}{|c|}{ Motivations for entering e-commerce and criteria for choosing } \\
e-commerce platform
\end{tabular}

\section{Appendix 5.2 Household income brackets}

\begin{tabular}{|l|l|}
\hline \multicolumn{2}{|l|}{ Monthly household income (baht) } \\
\hline Less than 2,500 & $70,001-90,000$ \\
\hline $2,500-5,000$ & $90,001-110,000$ \\
\hline $5,001-7,500$ & $110,001-130,000$ \\
\hline $7,501-10,000$ & $130,001-150,000$ \\
\hline $10,001-30,000$ & More than 150,000 \\
\hline $30,001-50,000$ & Prefer not to say \\
\hline $50,001-70,000$ & \\
\hline
\end{tabular}

\section{Appendix 5.3 Thai provinces}

\begin{tabular}{|l|l|l|}
\hline \multicolumn{3}{|l|}{ Thai provinces } \\
\hline Amnat Charoen & Nakhon Pathom & Rayong \\
\hline Ang Thong & Nakhon Phanom & Roi Et \\
\hline
\end{tabular}




\begin{tabular}{|l|l|l|}
\hline Thai provinces & Nakhon Ratchasima & Sa Kaeo \\
\hline Bangkok & Nakhon Sawan & Sakon Nakhon \\
\hline Bueng Kan & Nakhon Si Thammarat & Samut Prakan \\
\hline Buri Ram & Nan & Samut Sakhon \\
\hline Chachoengsao & Narathiwat & Samut Songkhram \\
\hline Chai Nat & Nong Bua Lam Phu & Saraburi \\
\hline Chaiyaphum & Nong Khai & Satun \\
\hline Chanthaburi & Nonthaburi & Si Sa Ket \\
\hline Chiang Mai & Pathum Thani & Sing Buri \\
\hline Chiang Rai & Pattani & Songkhla \\
\hline Chon Buri & Phangnga & Sukhothai \\
\hline Chumphon & Phatthalung & Suphan Buri \\
\hline Kalasin & Phayao & Surat Thani \\
\hline Kamphaeng Phet & Phetchabun & Surin \\
\hline Kanchanaburi & Phetchaburi & Tak \\
\hline Khon Kaen & Phichit & Trang \\
\hline Krabi & Phitsanulok & Trat \\
\hline Lampang & Phra Nakhon Si Ayutthaya & Ubon Ratchathani \\
\hline Lamphun & Phrae & Udon Thani \\
\hline Loei & Phuket & Uthai Thani \\
\hline Lop Buri & Prachin Buri & Uttaradit \\
\hline Mae Hong Son & Prachuap Khiri Khan & Yala \\
\hline Maha Sarakham & Ranong & Yasothon \\
\hline Mukdahan & Ratchaburi & \\
\hline Nakhon Nayok & & \\
\hline
\end{tabular}

\section{Appendix 5.4 Thai regions}

\begin{tabular}{|l|l|}
\hline Thai regions \\
\hline Province of residence & Other provinces in the eastern region \\
\hline Bangkok & Other provinces in the western region \\
\hline Other provinces in the north region & Other provinces in the central region \\
\hline Other provinces in the northeast region & Other provinces in the southern region \\
\hline
\end{tabular}

Note: Regions are macroregions and include options for 'Province of residence' and 'Capital city'. 
This text is taken from New Dimensions of Connectivity in the Asia-Pacific, edited by Christopher Findlay and Somkiat Tangkitvanich, published 2021 by ANU Press, The Australian National University, Canberra, Australia.

doi.org/10.22459/NDCAP.2021.05 